\title{
Scaling up social businesses in developing markets
}

\section{(Journal of Production - accepted version)}

\author{
Nancy M.P. Bocken ${ }^{1,2}$, Alison Fil ${ }^{2}$, Jaideep Prabhu ${ }^{3}$ \\ ${ }^{1}$ Industrial Design Engineering, Delft University of Technology, Landbergstraat 15, 2628 CE \\ Delft, The Netherlands, Tel. +31 (0) 1527845 21, Email: n.m.p.bocken@tudelft.nl \\ ${ }^{2}$ Institute for Manufacturing, Department of Engineering, University of Cambridge, Cambridge, \\ CB3 OFS, United Kingdom. \\ ${ }^{3}$ Judge Business School, University of Cambridge, Trumpington St, Cambridge CB2 1AG, \\ United Kingdom.
}

\section{Highlights}

- Social businesses address a social need while generating profits

- Key aims are increasing the number of customers and expanding the service/ offer

- We identify social scaling up strategies building on three cases and literature

- Market penetration, Market development, Product development and Diversification

- It shows the importance of focusing on income generated to 'finance social impact'

\section{Graphical abstract}

\author{
Aims to achieve \\ scale
}

Scaling methods

Increasing income generated
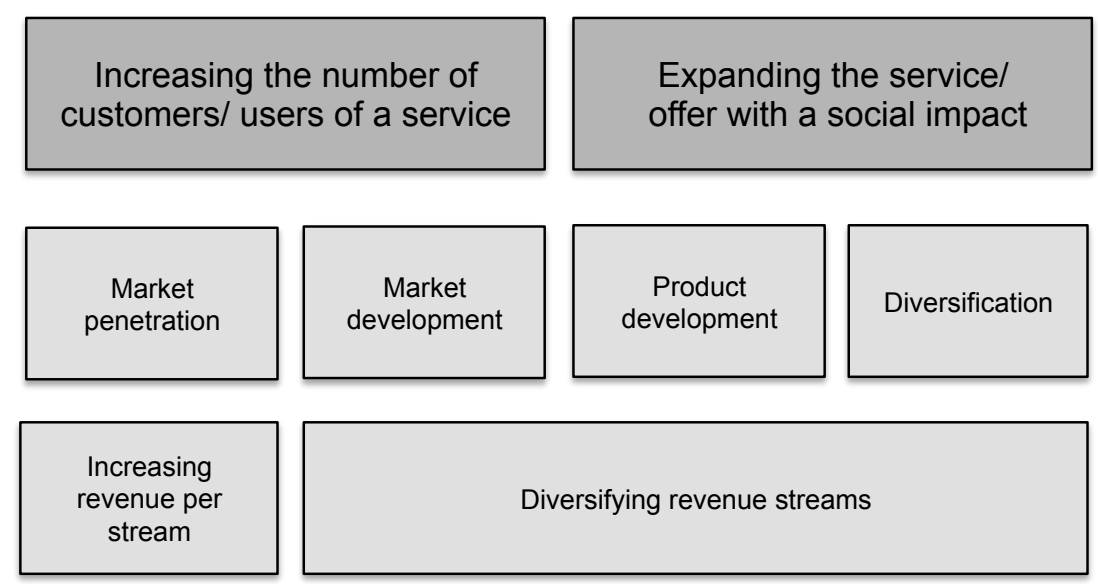

Graphical abstract: Scaling up methods for social businesses developed from Ansoff (1988) and the case studies from this research.

\begin{abstract}
Most of the world's poor live in developing markets and face unmet needs in core areas such as education, health, energy, sanitation and financial services. Developing markets offer businesses a vast opportunity for future growth as these economies emerge from low-income to middle-income status. A phenomenon of particular relevance in these markets is the social business, which addresses a social need while generating profits typically reinvested into the business itself. There is limited
\end{abstract}


understanding of the ways through which social businesses achieve scale. This paper investigates how social businesses can scale up. First, we define scaling up as "increasing the number of customers or members of a business as well as expanding its offer and maximising its revenues until it reaches millions of people." Second, using three in-depth case studies of social businesses that successfully scaled up according to these definitions, BRAC, Aravind and Amul, we identify scaling up strategies for social businesses. We identified market penetration, market development, product development and diversification as key strategies at different stages of business maturity. We find that there are two ways of increasing income generated that are linked to these four strategies: increasing revenue per stream and diversifying revenue streams. Our findings give insight to companies aiming to pursue social businesses and adds to the sparse literature on scaling up social businesses. A fruitful future research avenue would be to investigate the best sequence for applying these scaling strategies across companies and sectors over time.

Keywords: social business; business models; social entrepreneurship; developing markets; business strategy; sustainable growth.

\section{Introduction}

The world faces a growing population with increasing levels of consumption, even as a large part of humanity still lives in poverty (Royal Society, 2012). For instance, it is estimated that globally around 1.3 billion people live without access to electricity (OECD/ IEA, 2012). Furthermore, the threats of human-induced climate change exacerbate other threats to social and natural systems and place additional burdens on the poor (IPCC, 2014). New ways of doing business are needed to address these issues while mitigating the negative impact on the environment and society.

Developing markets are very much the focus of attention of businesses attempting to reach untapped markets with innovative solutions (Prahalad and Hart, 1999). Developing markets are increasingly important to the global economy as the developed markets of the West mature and saturate (Prahalad and Hammond, 2002). Over 4 billion people, more than half the earth's population, live in developing markets, and many of those people face unmet needs in core areas such as education, health, energy, sanitation and financial services. Meeting these needs through affordable and sustainable solutions offers businesses a vast opportunity for future growth. Indeed, as developing markets emerge from low-income to middleincome status, their development offers businesses the potential to make profits while also delivering significant social impact.

This raises a challenge for established and new companies on how best to design and distribute products for developing markets to optimise both economic viability, market penetration at scale, and social benefits. A further challenge arises from the fact that developing markets, in contrast with developed economies, lack many of the infrastructural and institutional features needed for markets to operate efficiently (OECD/ IEA, 2012; 2015). The lack of roads and electricity, for example, combined by the lack of clear property rights and well-functioning courts, increases the challenge that businesses face in scaling up solutions in developing compared to developed markets. On the other hand, new technology (such as mobile telephony) and knowhow (such as how to structure public-private partnerships) is increasingly available to be used in solutions to meet low-income communities' needs in emerging countries. The challenge therefore is how to develop and bring these solutions to the market to achieve large scale social impact (Polak, 2009).

Existing for-profit companies may try and move towards adopting more sustainable business models and incorporate societal and environmental concerns in the way 
business is done (Stubbs \& Cocklin, 2008; Bocken et al., 2013). For example they move towards business models where functionality is more important than ownership or business models where sufficiency (slow consumption) is encouraged (Bocken et al., 2014; Bocken and Short, 2016). However, the main purpose of conventional multinational businesses typically structured as a public limited company is to maximise shareholder value. New forms of businesses have emerged that are repurposed for society and the environment such as social enterprises and bcorporations allowing businesses to make these purposes part of their legal structure (Bocken et al., 2014; B Lab, 2016). In social enterprises the social mission is as important as financial viability (Alter, 2007), whereas benefit corporations or bcorporations are viewed as a "new legal tool to create a solid foundation for long term mission alignment and value creation" (B Lab, 2016). Existing companies such as Patagonia have restructured as benefit corporations in order to enable a socially and environmentally committed company to write those values into its articles of incorporation (Patagonia, 2014).

These types of businesses need social entrepreneurs with a personal commitment to a cause (Grassl, 2012). The distinction of social entrepreneurship (as opposed to traditional entrepreneurship) is in the value proposition itself, so, in the core of the business model (Grassl, 2012 in Bocken et al., 2014). The business models they pursue must be driven by a social mission; generate positive externalities (spill-overs) for society; recognize the centrality of the entrepreneurial function; and achieve competitiveness on markets through effective planning and management (Grassl, 2012). Social business models are conceptualised to include in the performance equation not only financial returns but also welfare-enhancing outcomes (Angeli and Kumar Jaiswal, 2016).

Businesses that both seek to deliver impact and generate profits may also be referred to as 'hybrid organisations' (Boyd et al., 2009) because they blur the boundary between for-profit and non-profit organisations. Nurtured by the failure of both forprofit and non-profit organisations to address social issues sustainably, hybrid organisations develop viable business models to create positive social and environmental change (Alter, 2007). These businesses are both market-oriented and mission-centred (ibid). Social businesses as an example of hybrid organisations address a social need while generating profits that are typically reinvested into the business itself. They seek to achieve scale to meet the magnitude of the needs they aim to fulfil and to achieve financial sustainability. The difference between a social business and a traditional for-profit business is that a social business generates profit to increase its social or environmental impact (Alter, 2007). Profit is a way to reach the company's goal; it is not in itself a primary goal (Grove and Berg, 2014; p. 157). The difference between a social business and a non-profit organisation is its financial sustainability as well as the business's involvement of the end customer. Microfinance for example creates a sense of pride and responsibility and generates (incremental) improvements as opposed to charity or donations (Yunus and Jolis, 1998).

Reaching scale is difficult for any business and even more so for organisations addressing a social issue as these tend to be harder to sustain financially (Karamchandani et al., 2009). Past research has studied the specific role of entrepreneurs in social scaling (Bradach and Grindle, 2014; Bradach, 2010; Dees, 1998). For example, to determine the factors that contribute to the success of social entrepreneurs, Bloom and Smith (2010) developed a model that identifies seven organisational capabilities, or "drivers", building up the acronym "SCALERS": staffing, communicating, alliance building, lobbying, earnings generation, replicating, and stimulating market forces. Research has also tested this model empirically (Bloom and Smith, 2010). While this is a useful categorisation of the activities of social 
entrepreneurs, our focus is on the strategic level of businesses trying to achieve social impact by growing their number of customers or members as well as expanding their offer and maximising revenues until they reach millions of people. In the literature, there is no clear link between a given strategy and the type of business, there is no hierarchy in methods separating the aim of the business and the ways to achieve these, and few authors have studied for-profit business growth and non-profit strategies to scale up social impact while maintaining financial sustainability through social businesses.

In this research, we aim to focus on what strategies social businesses could employ for scaling up social impact. This paper thus specifically focuses on the specific role of social businesses and how they can achieve scale in developing markets.

This research contributes to the sparse literature on scaling up social businesses. Although literature exists on scaling up for conventional for profit businesses as well as scaling up NGOs, there is less knowledge on scaling profit-generating social businesses (with the exception of work by Bloom and Chatterji, 2009 and Bloom and Smith 2010). Because scaling-up is a bottleneck for social businesses, we considered exploring methods specific to these businesses through case studies of three successful social businesses: Aravind, BRAC and Amul Dairy. Hence, we formulated the following research question: How can social businesses scale up in developing markets?

\section{Social businesses and the challenge of scaling}

This section reviews the literature on social businesses, scaling up and addresses the research gap of the lack of scaling methods for scaling up social businesses. Because of the lack of academic literature on scaling up social businesses, we refer to related literature on non-profits, for profits and grey literature.

\subsection{Social businesses in developing markets}

A social business addresses a social issue while being financially sustainable (Yunus et al., 2010). Yunus speaks of a new form of capitalism and a new kind of business based on the selflessness of people and whose purpose is to bring an end to a social, economic and environmental problem. In addition, the business generates enough income to cover its own costs but the investor makes no financial gain for himself: all profits are reinvested in the business itself (Yunus, 2010).

A plethora of literature can be found concerning the challenges presented by developing countries (Prahalad and Hart, 1999) as well as theories on how social innovation can bring people out of poverty (Polak, 2009; Radjou et al., 2012; Yunus et al., 2010). There is also extensive literature around designing approaches to innovation that are especially suited to emerging markets. Radjou et al. (2012) discuss a range of positive cases of jugaad innovation or simple innovations where limited resources are available (Radjou et al., 2012). A related term is constraint-based innovations (Kumar and Puranam, 2012), focused on innovating in circumstances with suboptimal conditions or constraints (e.g. lack of infrastructure; IEA/ OECD, 2012, 2015). Gandhian innovation is again a related term focused on innovating for emerging markets by focusing on availability, accessibility, affordability and appropriateness, for example, not over specifying and keeping it simple (Mashelkar and Sridhar, 2008). In their research, Kahle et al. (2013) and George et al. (2012), focus on the social effects of innovation in emerging markets. Hart and Christensen (2002) and Christensen et al. (2006) discuss emerging markets as a source of disruptive or and catalytic innovation respectively, creating entirely new markets. 
However, there is a discrepancy between the impacts an innovation can have and its actual scale once it is on the market. Innovative solutions adapted to developing markets often fail to reach their total potential impact (Soman et al., 2012). Social businesses seem to reach a bottleneck and generally remain small (Gradl and Jenkins, 2011). When a business fails to put their innovation into the hands of the millions of people who need it, all the effort put into designing an innovative solution adapted to developing countries is lost (Polak, 2009).

The literature typically identifies two core reasons for why scale is important: the immensity of the need to be addressed and the need for economies of scale to achieve financial sustainability (Hammond, 2007; Prahalad, 2004). If we define the Bottom of the Pyramid (BoP) to be those of the global population living on less than $\$ 2.5$ per day this adds up to a total of 4 billion people (Hammond, 2007). For a population with limited resources and low access to products and services, this offers a huge untapped opportunity for businesses. However, while this market is large, only a few countries in which such markets exist are large: China, India, Brazil, Mexico and Indonesia (Prahalad, 2004). And so, to achieve scale, an innovation must be adapted and transferable to other countries. Further, for many social businesses, reaching economies of scale is necessary because of the stringent price-performance ratios and low margins per unit (Prahalad, 2004). In practice, however, scaling remains a major challenge for hybrid organisations (Haigh and Hoffman, 2012) and for-profit businesses aspiring to be sustainable (Bocken et al., 2014; 2015) for a number of reasons including the lack of finance, inadequate infrastructure and the general lack of resources (Gradl and Jenkins, 2011).

Figure 1 includes an overview of hybrid organisations - those with a clear social mission and a profit motive (Alter, 2007) and the cases discussed in this paper. Social enterprises are defined as any business venture created for a social purposemitigating/reducing a social problem or a market failure-and to generate social value while operating with the financial discipline, innovation and determination of a private sector business. (www.virtueventures.com in Alter, 2007). While this is perhaps the most common term, Alter (2007) argues there are multiple forms along the hybrid spectrum. In this paper, we use the term "social business" to represent the diverse cases in the hybrid spectrum.

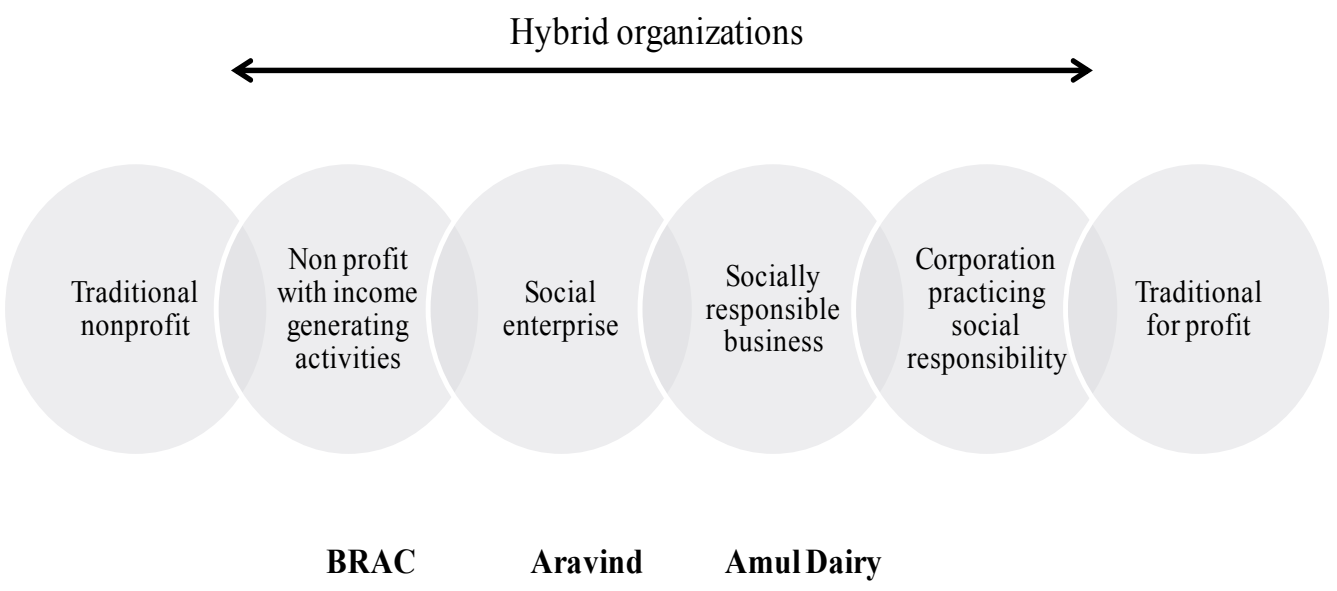

Figure 1. Choice of case studies within the hybrid spectrum. Source: Developed from Alter's (2007) Social enterprise typology 


\subsection{Definitions of scaling up}

There are numerous definitions of the term scaling-up. Scaling-up usually refers to the process of increasing the number of customers or, to a wider extent, the number of members involved or the number of partnering organisations. But the definition can be expanded to also include increasing the impact of a business. The Oxford dictionary defines scaling-up as increasing in size, number and extent. The most complete definition of the different types of scaling-up social organisations, more specifically NGOs, is defined as follows (Uvin and Miller, 1996):

- Quantitative scaling-up: increasing the number of customers (or members) of a company or its geographical working area

- Functional scaling-up: expanding the number and the type of activities, moving from the delivery of a product or service to a business offering an entire system helping people get out of poverty

- Political scaling-up: moving from service delivery to empowerment and change in structural causes of underdevelopment

- Organisational scaling-up: diversifying sources of subvention, creating activities that generate income

This definition uses the perspective of social outreach and impact, but does not include the development phases of a business.

The Center for Advancement of Social Entrepreneurship (CASE) at Duke University includes the temporal aspect in scaling-up (Murray et al., 2010, p. 11; Clark, 2012). They discuss a sequence of activities where prompts include the factors which highlight the need for innovation (e.g. a crisis or certain public need), proposals and ideas are the idea generation phases, prototyping and pilots are informal and formal activities to refine and test ideas, sustaining is the phase where ideas are sharpened up and strategies for long-term viability of the organisation is sought (Murray et al., 2010). Scaling and diffusion is the phase where strategies can spread, for example through organisational growth or licensing and franchising and systemic change is the phase where many elements come together such as social movements, new business models and laws and regulations to make the social innovation a success (ibid.).

The research centre defines scaling social impact as the process of closing the gap between the real and ideal conditions regarding particular social needs or problems (Murray et al., 2010). Scaling up a social business is referred to as growing to match the level of need (Gabriel, 2014). However 'needs' and levels of needs are highly subjective, which makes this very difficult to quantify. For the purpose of this paper, a more quantifiable definition will be used which derives from the definition of scaling up a conventional business. Scaling up a business usually refers to its growth in terms of sales throughout the business lifecycle, as shown on the following graph, adapted from the literature on the business lifecycle (Porter, 1998). Figure 2 includes the business life cycle. 


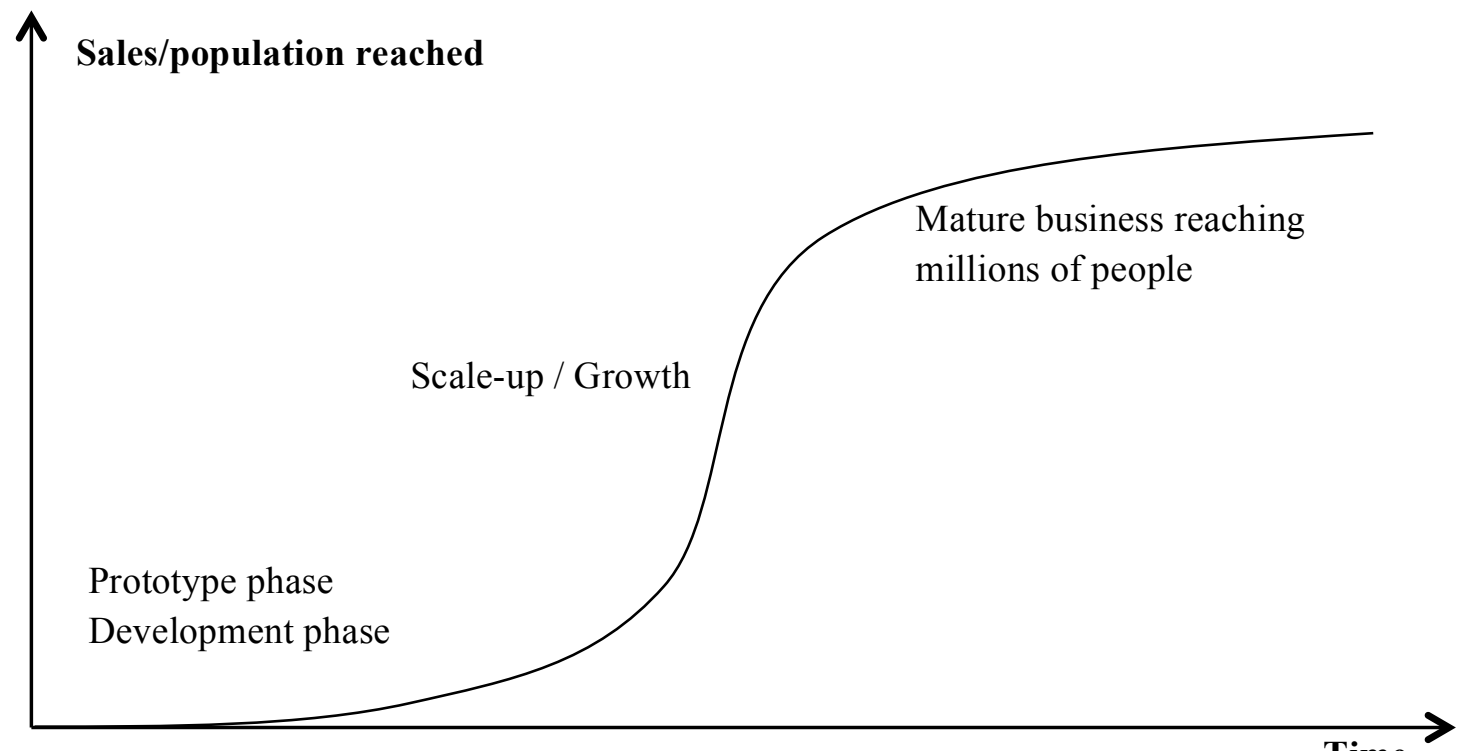

Figure 2. Business life cycle adapted from Porter (1998)

Time

The scaling-up phase corresponds to the period in between the development phase of a business and the mature phase. When companies grow, it is commonly regarded that economies of scale can be reached, where cost can be saved due to the increasing scale of the business, for example through reduced capital, marketing and design cost per product (Silberston, 1972). Whereas scale may be viewed in the size of production operations or turnover, we take a customer-centric view in this paper. Drawing on the definition by Polak (2009) of the scale that a social business should achieve to have a significant impact; we consider a business to be mature when it reaches large numbers (i.e. millions) of people. By reaching greater numbers of beneficiaries a social business can reach greater levels of positive impact. By doing this as part of its social business, it can reach economies of scale to do so effectively.

Specifically, considering elements from all these different definitions, the definition of scale we use for this paper is the following: "Increasing the number of customers or members of a business as well as expanding its offer and maximising its revenues until it reaches millions of people."

With this definition in the particular context of this research, the following questions arise: What makes some social business reach millions of people? Which methods exist to scale up social businesses? To gain further understanding, we expanded our literature search to cover the existing scaling-up methods used by for-profits and nonprofits, because of the lack of literature on investigating scaling up social businesses.

\subsubsection{Scaling up for-profits}

Scaling up for-profit organisations is usually referred to as growing a business. The most widespread growth typology is Ansoff's growth matrix (Ansoff, 1988) which is shown in Table 1. The table explains the four strategies businesses can use to grow.

Table 1. Ansoff matrix. Source: Ansoff (1988) Market penetration

\section{Product development}

Get the customer to increase his level of Increasing sales by launching new purchase or frequency of purchase.

Move the customer away from competitors.

Convincing new potential clients. products on current markets. A company can modify a product, create several versions or develop new models and sizes. 


\section{Market development}

Increasing sales by introducing current products to a new market (regional, national, international) or by developing new market segments with focused products, using new distribution networks or other communication channels.

\section{Diversification}

This strategy is used when the potential market is outside the current market of the company. Diversification can be done using technology complementary to the current activity. Horizontal diversification is also possible to satisfy the same customers. It is also possible to diversify by creating a conglomerate (different activities for different markets). Diversification is the most risky strategy since both product and market development are required.

However some of these strategies for growth are not suitable for social businesses. For instance, increasing the frequency of purchase and attracting new customers are not always applicable to social businesses.

\subsubsection{Scaling up non-profit organisations}

Existing methods (paths) to scale up non-profit organisations may be more quantitative, functional (focused on the type of activities), political (focused on networking and politics) or organisational (diversifying funding to increase financial viability and internal management) (Uvin and Miller 1996). However, these are not necessarily suitable for social businesses, because generating income is core to social businesses (Alter, 2007). In contrast, NGOs are often externally funded for example through grants or depend on people supporting the cause in-kind (Lewis and Kanji, 2009). Social businesses usually require funding at the early stages of the business, but need to generate further revenues to support subsequent scaling-up, whereas NGOs can also rely on other forms of scaling up (e.g. in-kind support or grants). Moreover, not all paths are at the same level. Certain paths as identified by Uvin and Miller (1996) refer to increasing the number of customers (spread) whereas others refer to increasing the organisation (horizontal integration) while still others speak of best practices to accompany scaling-up (internal management). Innovation as a driver of growth is not mentioned in this list. But, as we know, inclusive innovation, which benefits the disenfranchised, adds value and creates growth (George et al., 2012).

Looking more precisely at scaling social enterprises or more generally start-ups, one of the main enablers for growth is access to financial capital (Bocken, 2015). There are a certain number of possible financing sources for a social venture: crowdsourcing platforms, social investment brokers, grant makers, innovation challenge funds, micro-funding, social lenders, social venture capital funds, and specialist banks (Shanmugalingam et al., 2011). Venture capital can help young firms grow faster, create more value and generate more employment than other start-ups without such support. It is a determinant of innovation-driven growth (Keuschnigg, 2004) and sustainability (Bocken, 2015). Venture capital can add value to the business through providing managerial know-how in addition to access to capital. Lack of access to financial capital can be a limiting element to scaling-up (Bocken, 2015). On the other hand, developing partnerships to access both capital and know-how can be a way to scale up. Social business, having profit motives, would come closer to 'conventional businesses' in their financing needs than non-profits.

\subsection{The need to investigate scaling up social business}


The number of definitions and methods for scaling-up illustrates the difficulty of this process. Moreover, reaching scale is difficult for any business and even more so for companies addressing a social issue as these tend to be harder to sustain financially (Karamchandani et al., 2009). Overall, several points can be raised regarding the existing scaling-up strategies identified in literature. First, there is no clear link between a given strategy and the type of business, the stage of the business or the impact that the business is attempting to reach. Second, there is no hierarchy in methods separating the aim of the business and the ways to achieve these. Finally, few authors have investigated the combination of for-profit business growth and nonprofit strategies to scale up social impact while maintaining financial sustainability.

Our literature review reveals that while scaling up is necessary for social businesses, many social businesses fail to make a significant social impact because of the lack of scalability of their business. Although literature exists on scaling up businesses as well as scaling up NGOs, there is less knowledge on scaling profit-generating social businesses (with the exception of work by Bloom and Chatterji, 2009 and Bloom and Smith 2010). Because scaling-up is a bottleneck for social businesses, we considered exploring methods specific to these businesses as a main objective. Specifically, we formulated the following question for this paper: How can social businesses scale up in developing markets? Whereas some authors view the role of entrepreneurship as indispensable to bringing real change of magnitude in the world (Grassl, 2012), others regard technology as a means to do more with fewer resources and for more people (Prahalad and Mashelkar, 2010). This research seeks to clarify the factors contributing to the scaling up of a social business and the typical strategies to achieve scale.

Figure 3 includes the analysis framework for this paper. This framework is based on the principles of coding (Corbin and Strauss, 1990), where data are classified in a hierarchical way to develop new theories. The three aims in Figure 3 are based on the definition used in this paper, "Increasing the number of customers or members of a business as well as expanding its offer and maximising its revenues until it reaches millions of people". The four methods are based on Ansoff's (1988) strategies, which are identified as a key framework for for-profit benefits and may also have important merit for social businesses. "Increasing income" is added, because financial viability is viewed as a key strategy for social businesses that are often neglected to the detriment of these types of organisations. 


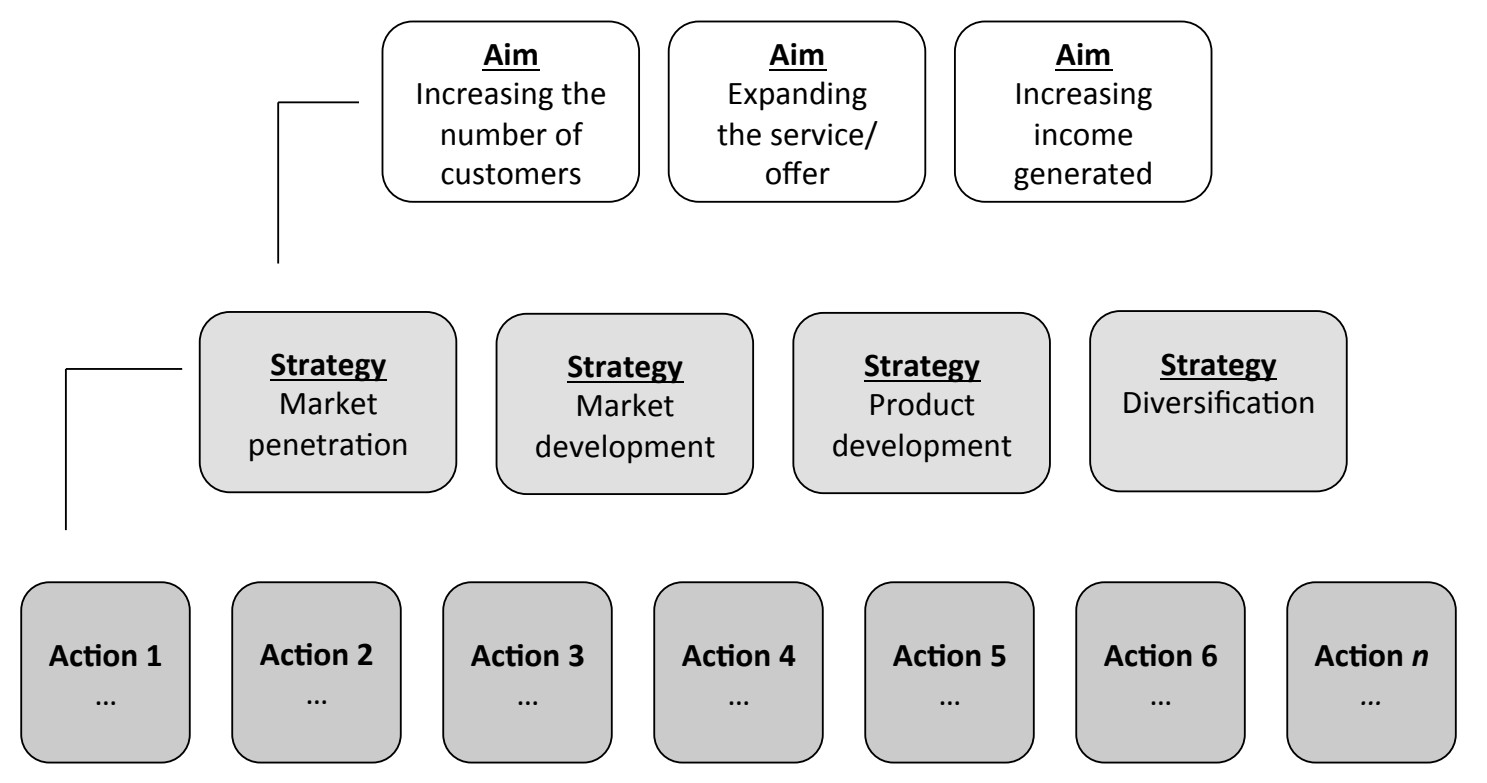

Figure 3. Analysis framework to clarify methods to scale up used for the case studies. Note strategies based on Ansoff (1988); Aims based on definitions of scaling up in this paper.

\section{Method}

The objective of this research was to develop insight into how social businesses can achieve scale. How and why questions of how certain (social) phenomena work are particularly suited to investigate through case study research (Yin, 2013). Furthermore, because of the contemporary and applied nature of this question, and the fact that it is a research area over which the researchers had little to no control, a case study method was chosen (ibid.).

The cases were selected based on the companies: 1) being established social businesses, namely generating social impact while generating an income and 2) having achieved significant scale over time. The case analysis is done in retrospect, so that an analysis of the key events and strategies to achieve scale can be made. Typical examples were selected of such social businesses, which were based on expert insight into the topic rather than statistical sampling (Seawright and Herring, 2008). Furthermore, the focus was on case studies where quantitative data are available because of the quantitative nature of the scaling definition in this paper: "Increasing the number of customers or members of a business as well as expanding its offer and maximising its revenues until it reaches millions of people."

Multiple case studies were included because there was no single critical case that would help answer the question. Due to the need to develop a deep analysis and look at the evolution and strategies of the companies since their beginning, only three companies were selected: BRAC, Amul Dairy and Aravind Eye Care. The choice was made to ensure a variety of industries as well as different types of hybrid businesses as was shown in Figure 1. The small sample size, mainly due to the limited number of large-scale social businesses, allowed for an in-depth analysis of each of the individual cases over time (in contrast to a multitude of superficial cases). To analyse the data a within and cross-case analysis were performed to understand the cases in detail, but also seek to identify common patterns across the cases (Eisenhardt, 1989).

Our sample consisted of cases where millions of people have been impacted as also mentioned in our definitions of scaling. We considered but did not include in our 
sample cases of social businesses that had either failed or had not scaled even a long time after founding for three reasons. First, social businesses that fail or do not scale are the norm. The challenges of meeting social needs while ensuring financial viability in resource poor environments lacking key infrastructure and institutions means that most social business struggle to survive and grow. Consider SELCO, a solar lighting social enterprise based in Bangalore, India that has been in operation since 1995 (Radjou et al., 2012; Prabhu and Jain, 2015). Despite having a very committed founder and a highly creative business model, the enterprise has 'only' reached about 200,000 homes after 20 years of operation (Radjou et al., 2012). Social businesses that succeed and scale are rare. Studying them therefore provides more insight into our research questions than studying failed businesses does. Second, by definition it is hard to track and get data on social businesses that have failed. Because our method requires using verifiable qualitative and quantitative data on the scaling process over time, we focus on large, successful social businesses on which such data are available. Nevertheless, we suggest in the conclusion section of the paper that future research may consider extending our method to a sample that included comparable social businesses that failed or did not scale over time. Finally, scale is crucial in the developing world for two reasons: truly meeting the needs of millions, even billions of people in order to reduce absolute poverty (and associated social problems) as well as to achieve financial viability. Small or niche social businesses, no matter how ingenious they may be, do not make an appreciable dent into addressing global poverty. As Sir Fazle Hassan Abed, the founder and Chairperson of BRAC, puts it: "Small may be beautiful but large is necessary." (Smillie, 2009).

The data primarily came from company reports and existing case studies and was completed by a questionnaire, which was either exchanged over the phone or via email for two of the three companies, BRAC and Aravind, because of logistical and budget constraints (Tables 2). We made multiple attempts to contact senior management at Amul, but unfortunately did not receive a response. Fortunately, there are extensive secondary data on Amul that we were able to access for our study. Data gathered on the cases include: books, existing case studies and reports as cited in the case section and interviews by means of a questionnaire. The questionnaire can be found in Appendix A. It focuses on the business model of the company and its social aspects, the current and future scale of the business and the types and strategies of scaling-up the company has used to reach it current scale.

Table 2. Companies selected for case studies

\begin{tabular}{|l|l|l|l|l|l|}
\hline Company & Purpose & $\begin{array}{l}\text { Scale } \\
\text { (annual) }\end{array}$ & Employees & Industry & Location \\
\hline $\begin{array}{l}\text { Case A: } \\
\text { BRAC }\end{array}$ & $\begin{array}{l}\text { Large-scale } \\
\text { NGO with } \\
\text { income } \\
\text { generating } \\
\text { activities }\end{array}$ & $\begin{array}{l}\text { 110 } \\
\text { million } \\
\text { people } \\
\text { reached }\end{array}$ & 120,000 & $\begin{array}{l}\text { Health, } \\
\text { microfinance, } \\
\text { agriculture }\end{array}$ & $\begin{array}{l}\text { Founded in } \\
\text { Bangladesh } \\
\text { with operations } \\
\text { in Bangladesh, } \\
\text { Pakistan, } \\
\text { Liberia, } \\
\text { Uganda etc. }\end{array}$ \\
\hline $\begin{array}{l}\text { Case B: } \\
\text { Aravind } \\
\text { Eye Care }\end{array}$ & $\begin{array}{l}\text { Financially } \\
\text { sustainable } \\
\text { social } \\
\text { business }\end{array}$ & $\begin{array}{l}3.1 \\
\text { million } \\
\text { patients } \\
\text { treated }\end{array}$ & 297 & Eye care & India \\
\hline $\begin{array}{l}\text { Case C: } \\
\text { Amul } \\
\text { Dairy }\end{array}$ & $\begin{array}{l}\text { Large FMCG } \\
\text { business } \\
\text { with a social } \\
\text { mission }\end{array}$ & $\begin{array}{l}3 \text { million } \\
\text { milk } \\
\text { producer } \\
\text { s }\end{array}$ & 750 & & $\begin{array}{l}\text { Dairy } \\
\text { products }\end{array}$ \\
\hline
\end{tabular}


The data was analysed following two axes: a timeline of the company's scaling up methods (1) and a classification of the methods (2) using the framework in Figure 3. Companies' actions are gathered; these are classified into more generic methods, which are linked to a broader aim of the business as can be found in Figures 6, 8 and 10 in the Section 4 - Case study results.

\section{Case study results}

This section described the case findings for BRAC, Aravind and Amul individually followed by a cross-case analysis.

\subsection{Case study BRAC}

The BRAC case study is organised by the evidence of scaling and approach, and the timeline and strategies.

\subsubsection{BRAC evidence for scaling and approach}

BRAC is one of the largest NGOs in the world, serving 135 million people worldwide in 11 different countries (BRAC, 2013a). Despite being an NGO, many of its activities are income generating such as microfinance and social enterprises. Profits generated from these activities are fed back into the organisation's core development programs, making the NGO approximately $80 \%$ self-funded (McDonald and Ruiters, 2012). The BRAC model is built on local capacity building. This involves working with the poor and marginalised to identify the capacities needed for self-help and helping to build them. The assumption is that given increases in local capacities, local actors can often solve many of their own problems (Alvord et al., 2004). Scale is an imperative at BRAC due to the magnitude of the need to be addressed (May, 2011; Saleh and May, 2013, Chap. 1).

BRAC's activities are based on a progressive path. It reaches the very poor with their Targeting the Ultra Poor program that loans assets to help the poor make a living. People then gradually start gaining access to microfinance and start small businesses. BRAC supports its members throughout this move up with training and access to healthcare with the final aim that its members become autonomous and fully functioning members of society (MacMillan, 2013; BRAC, 2013b).

Due to the complexity of BRAC's mission, understanding the needs and adapting the model is key, which is why in order to achieve scale, the company uses a pilot replication model: several solutions are tested and improved before being taken to scale (Ahmed and French, 2006). For instance, BRAC piloted an incentive-model to increase shashto shebikas' (local health community helper) success rates: 50 Takas were offered for every new or relapsed case they identified. This pilot was not scaled up because it was difficult to monitor that the cases were not being manipulated (Islam and May, 2013).

To reach people in disperse regions with little access to knowledge, BRAC used village societies with local village intermediates to train people in addition to being the distributors of BRAC's services. For its microfinance program for example, BRAC has a total of 200,000 village organisations with a total of 4 million members (BRAC, 2013c). Each member has a personal passbook that recaps her loans, savings account and repayments, which is updated weekly by a program officer. A borrower must attend village organisation meetings where training concerning how to grow small businesses and information concerning BRAC services are advertised. To 
overcome the lack of knowledge, BRAC builds schools and trains teachers (Yasunuga, 2014). Its education program exists in seven countries and aims to help those who are left out of the formal education system due to poverty, discrimination or lack of infrastructure (BRAC, 2015). In 2013, for instance, it launched 257 new boat schools in hard-to-reach areas (BRAC 2013a). The drivers of poverty being systemic, a large range of activities is necessary to address it. This is why BRAC developed several activities (functional scaling-up) before spreading and increasing its market penetration (Islam and May, 2013).

Due to its nature as an NGO, an obstacle BRAC was confronted with was financing its operations, especially in the beginning before it reached scale and got involved in income-generating activities. As a result, BRAC relied on grants during its scaling-up. For example, in 2004, it received a grant from FIDELIS enabling it to cover a further 28 million people (Islam and May 2013). To overcome the lack of communication channels in emerging markets, BRAC spread its model by training other NGOs. When the Global Fund was launched, BRAC was a key player in the training of other NGOs on its tuberculosis program (Islam and May 2013). Public online access to case studies is another way to spread knowledge - BRAC has its own research paper database which is accessible online. This is an approach very specific to social businesses where other organisations are not seen as competitors but partners.

\subsubsection{BRAC timeline and strategies}

As illustrated in Figure 5, BRAC started by expanding its activities before expanding geographically. Starting off as a temporary relief organisation in 1971, BRAC shifted to long-term development needs in 1973 (Ahmed and Rafi, 2006). It then developed activities such as microfinance, health, rural development program, targeting the ultra poor program, social enterprises focused on livestock or textiles (Islam and May, 2013, Chapter 2). Aarong for example, is a ready-to-wear social enterprise employing mainly marginalised rural women (BRAC, 2013a). For each activity, the model was evaluated, reviewed and modified. For instance, microfinance was originally done by group lending: each time a member took up a loan, all the members in the group needed to approve and support the member to repay the loan. It was also directed to both men and women (ibid.). However, today BRAC focuses its microfinance program mainly on women, because BRAC has found that women save more and are less mobile than men, especially if they have children. Group loans do not exist anymore but village organisations still do and weekly meetings must be attended by borrowers.

BRAC's scaling strategy is based on three learning stages (Korten, 1980). A company must start by learning to be effective: creating a fit between the program model and the beneficiaries' needs. Then the company must learn to be efficient and reduce the inputs required per unit of the desired outcome. And finally the company must learn to expand. It was only after completing these stages that BRAC started its international expansion in 2002 as shown in Figure 4. However, the various types of scaling are interconnected and achieving scale often requires a combination of different strategies, which will now be detailed. 


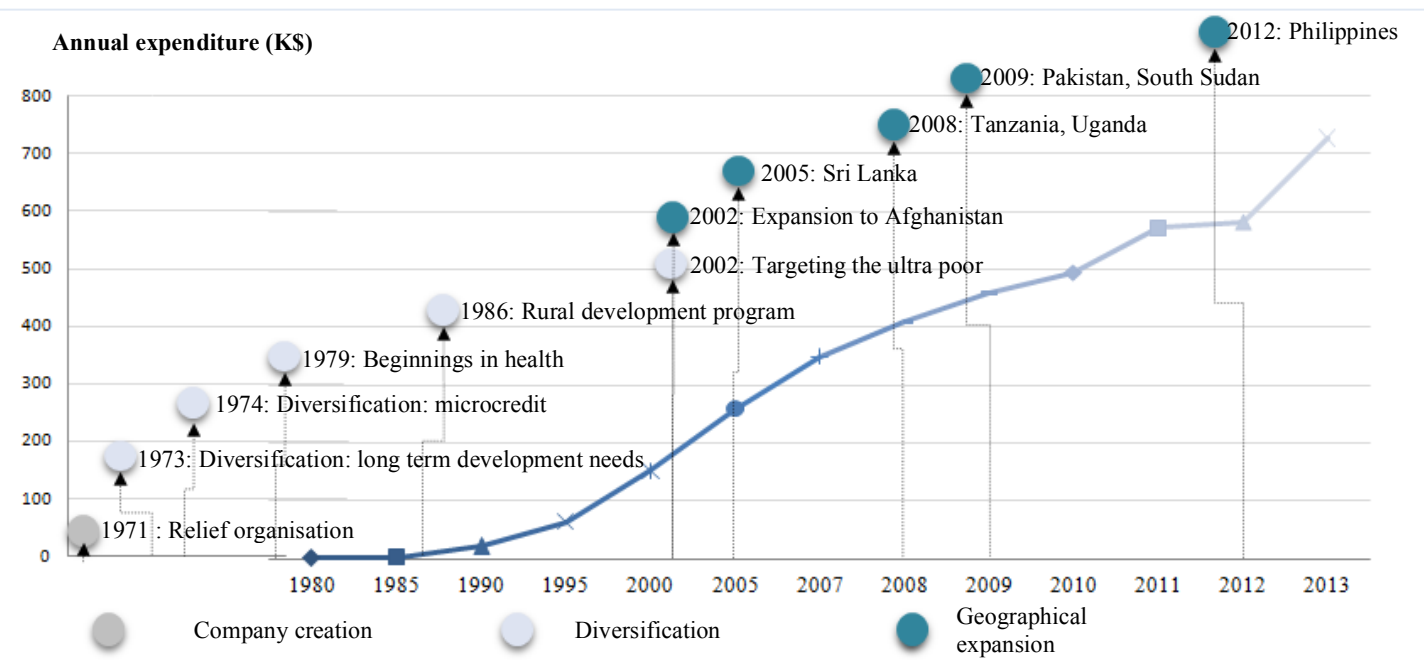

Figure 4. BRAC scaling timeline, sources: Islam and May (2013, Chapter 2), BRAC (2013a, b, c)

The data gathered for this case study led to the following classification of BRAC's strategies to achieve scale shown in Figure 5.

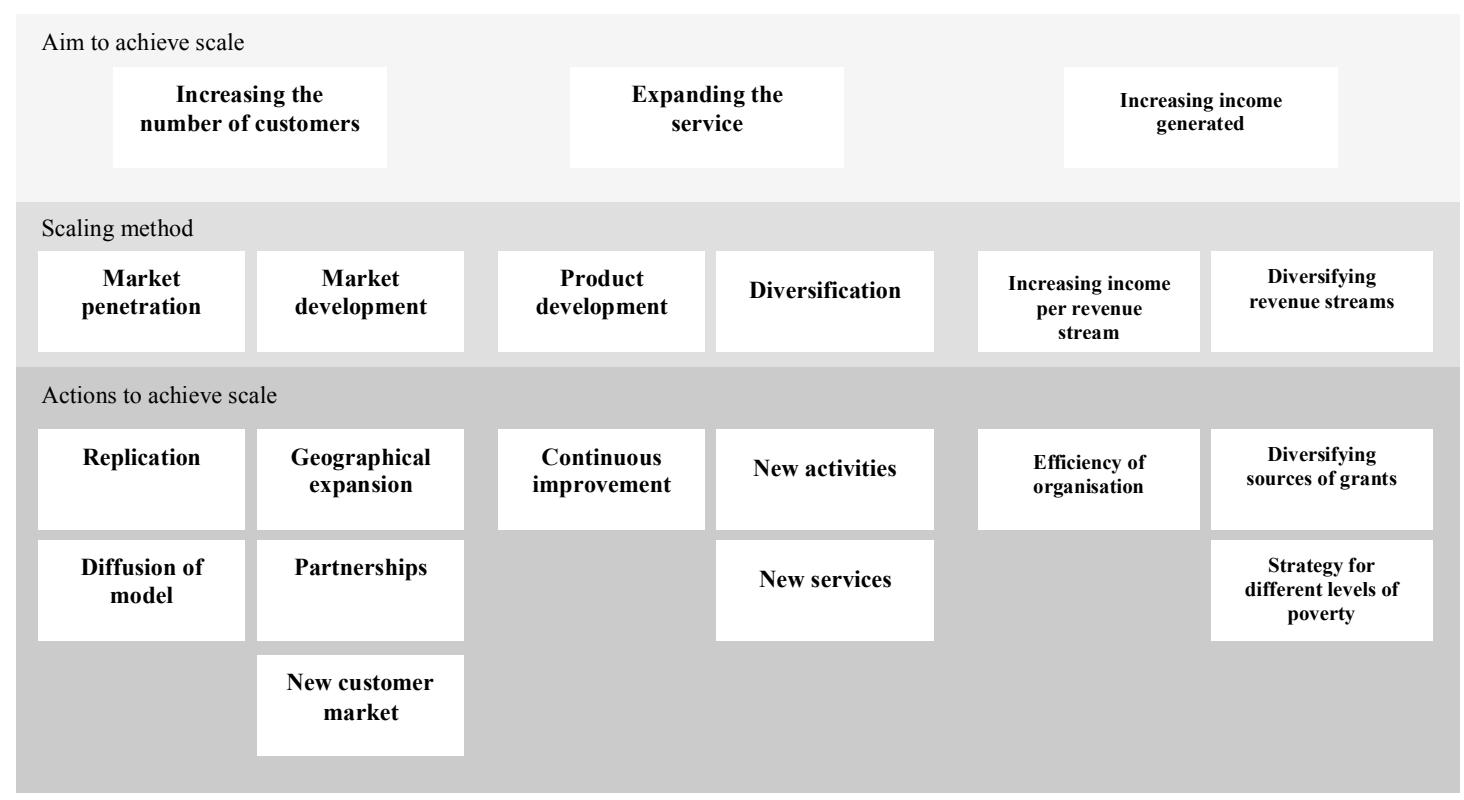

Figure 5. BRAC scaling strategies. Note: the first four methods are based on Ansoff's matrix (1988) and are complemented by 'increasing income generated' and 'diversifying revenue streams'

To spread its model and increase market penetration, BRAC used replication and diffusion. In terms of diffusion of the model, as part of the National Tuberculosis Program for instance (Islam and May, 2013), BRAC trained other NGOs on its best practices and helped them replicate its model. To develop new markets, BRAC expanded geographically, established tactical partnerships and explored new customer markets. Geographical expansion faces the following challenges: new constraints (e.g. mobility of people in Africa), government restrictions on NGOs, visa challenges, finding trained and competent local staff and scepticism that the model can be replicated to other countries with different cultures (Islam and May 2013, 
Conclusion Chapter). To tackle issues linked to geographical expansion, BRAC developed partnerships. For example, it worked closely with the government and the National Tuberculosis Program to expand its model throughout Bangladesh (Islam and May 2013). This enabled them to scale up from 60 sub-districts to 297. Another example is its partnership with the NoVo foundation to support education and empowerment of adolescent girls in South Sudan and Afghanistan (BRAC, 2013a). The company also developed new markets: in 1998 it established microfinance programs in the slums of Dhaka (Islam and May, 2013, Chapter 9). This new market posed many challenges: far less social capital, identification to home villages rather than current location, and mobility of population. BRAC had to adapt its model by focusing on particular groups of population, such as garment factory employees for instance.

To increase its social impact, the company is constantly improving the service it offers as well as developing new activities and services. In 1975, 4 years after BRAC was founded, the research entity RED (Research and Evaluation Division) was founded to analyse and evaluate activities (Ahmed and Khondkar, 2010). For instance, it developed its Challenge the Frontiers of Poverty Reduction - Targeting the Ultra Poor (CFPR-TUP) program to reach people who could not access even the lowest level microfinance services (ibid).

In addition to increasing impact by reaching more people more effectively, scale can also be measured in terms of income generated or annual budget. A strategy that BRAC used to reduce its costs per unit was improving organisational effectiveness. For example, offices are audited on a regular basis to control their use of resources. This also increased credibility with donors, a key for scale-up to happen (Ahmed and French, 2006). To increase revenue streams, the company used diversification of grants as well as market segmentation. BRAC's microfinance model is based on a ladder-type incremental system (Matin and Yasmin, 2004). People are gradually helped out of poverty by climbing different rungs on the ladder (ibid). At each level, BRAC's offer, approach and income model is different. For instance, BRAC's microloan model begins with loans of small land or assets that will then expand into small amounts of money (Dabi loans range from $\$ 50$ to $\$ 300$ and Progoti loans from $\$ 300$ to $\$ 5000$ ) to develop a small rural business (BRAC, 2013c).

\subsection{Case study Aravind Eye Care}

The Aravind Eye Care case is organised by the evidence of scaling and the timeline and strategies.

\subsubsection{Aravind evidence for scaling and approach}

Aravind Eye Care was created from Dr Govindappa Venkataswamy's efforts to end needless blindness in India (Rubin, 2001). The company runs a system of hospitals and eye care centres in India. Its quality and operational effectiveness is unmatched in the world (Rangan, 1993). It treats over 3.1 million patients annually. Most of its patients (around 50\%; Aravind, 2013) do not pay for surgery and the remaining patients pay a much lower price than in other hospitals. Despite this, the business is highly profitable due to its high efficiency of operations and economies of scale.

From the beginning, Aravind was confronted by a lack of local research, manufacturing capacity for Intra Ocular Lenses (IOLs) necessary to treat cataract, technology and know-how (Rangan and Thulasiraj, 2007). To overcome this, Aravind developed an internal research lab as well as a manufacturing entity, Aurolab (Figure 6 ). The company now produces 600,000 lenses annually and sells products all over 
India and internationally (Rubin, 2001). This is an additional source of revenue for the business. The integration of manufacturing solved the problem of the high cost supply of lenses from abroad (Rangan and Thulasiraj, 2007).

Staff (e.g. ophthalmic paramedics, ophthalmologists, eye care professionals, managers) receives intensive training. Aravind's training of over 500 eye care professionals is a solution to deal with the lack of skilled labour in this particular area in India (Aravind, 2013). However it is also a limiting and time-consuming constraint vis-à-vis scaling-up. The general lack of knowledge of eye care practices as well as scepticism is tackled by community outreach programs (source: interview). This service-to-the-doorstep program educates people on eye care and identifies if they need surgery (Aravind, 2013). It increases awareness, influences health-seeking behaviour and grows the market by reaching the unreached (Thulasiraj and Dhivya, 2014). The 3,000 camps conducted in 2013 resulted in 500,000 patients being screened and 90,000 patients that underwent surgery (Aravind, 2013). Additionally, to solve transport issues that are a problem for patients time-wise and cost-wise to reach hospitals, small eye care centres are being implemented as close to the population as possible. Finally, the need for additional services around eye care (e.g. retina and vitreous, ophthalmology, uvea, cornea) have generated the creation of small eye care distribution centres.

To tackle the cost of operations (surgery and medical care), Aravind has developed high operational effectiveness. The time in the operating room is optimised via high preparation beforehand from qualified ophthalmic assistants. Most operating rooms use two or three operating tables (Rangan and Thulasiraj, 2007). The support staff as well as instruments used are highly coordinated to ensure efficiency (Rangan and Thulasiraj, 2007). As a result, Aravind's solution costs about $\$ 10$ per surgery, making it highly affordable, in comparison to the USA where the service could cost $\$ 1,650$ for the same quality of operation (Rubin, 2001).

\subsubsection{Aravind timeline and strategies}

To begin the analysis of scaling-up methods, a timeline of Aravind's evolution was developed (Figure 6). This timeline looks at Aravind's capacity in terms of hospital beds throughout time and the methods the company used to scale up. The timeline shows that Aravind's strategy was first to penetrate a given region before expanding geographically to other states, and then diversify its activities, adding a manufacturing unit and a training, research and consultancy entity. Aravind focused on market penetration in its early stages due to its business model, which becomes sustainable if large volumes are reached. The methods used by Aravind are summarised in Figure 7. 


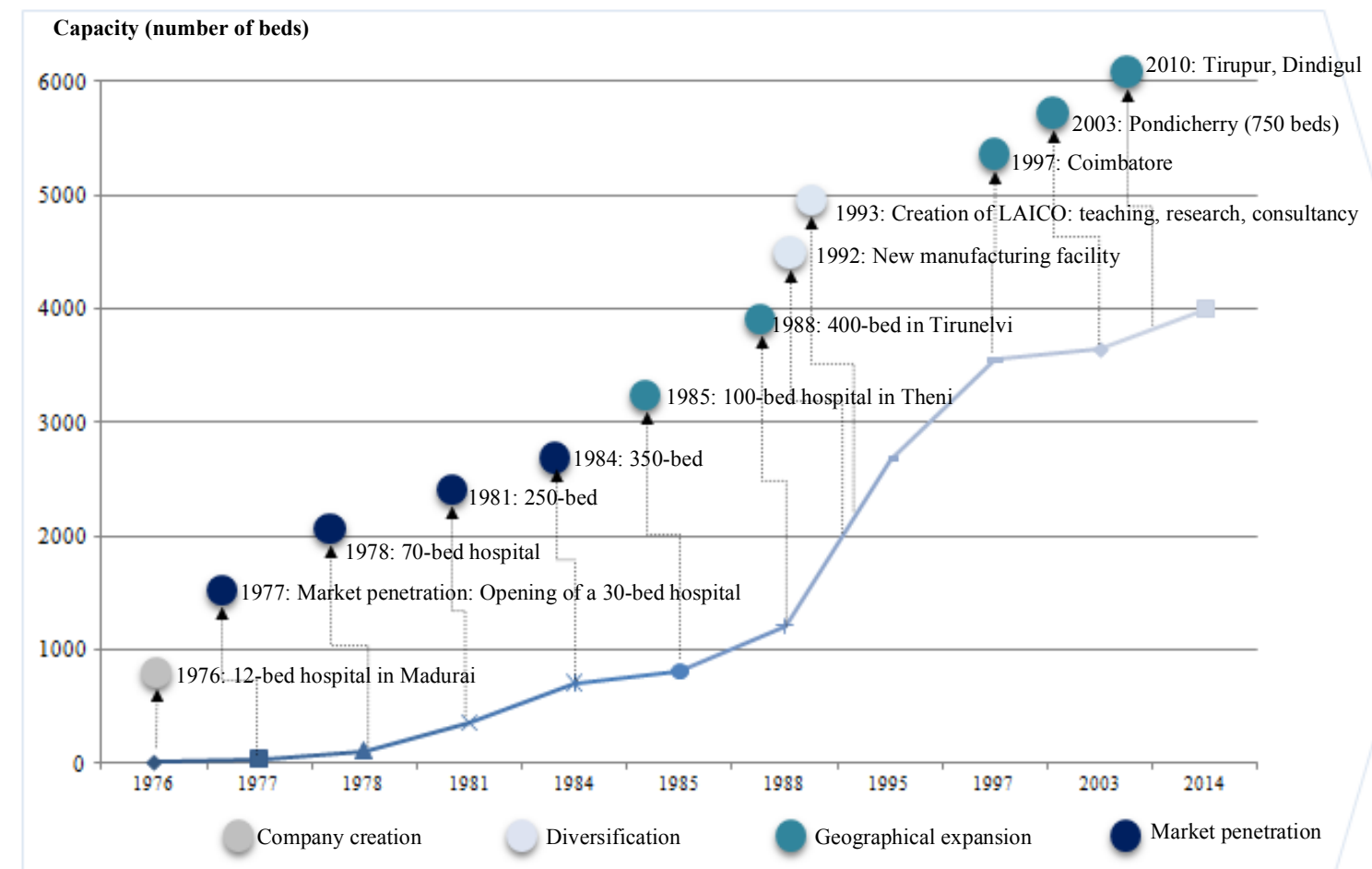

Figure 6. Aravind scaling timeline, Source: Manikutty and Neharika (2004), Rubin, (2001), Aravind (2014), Mehta and Shenoy (2011)

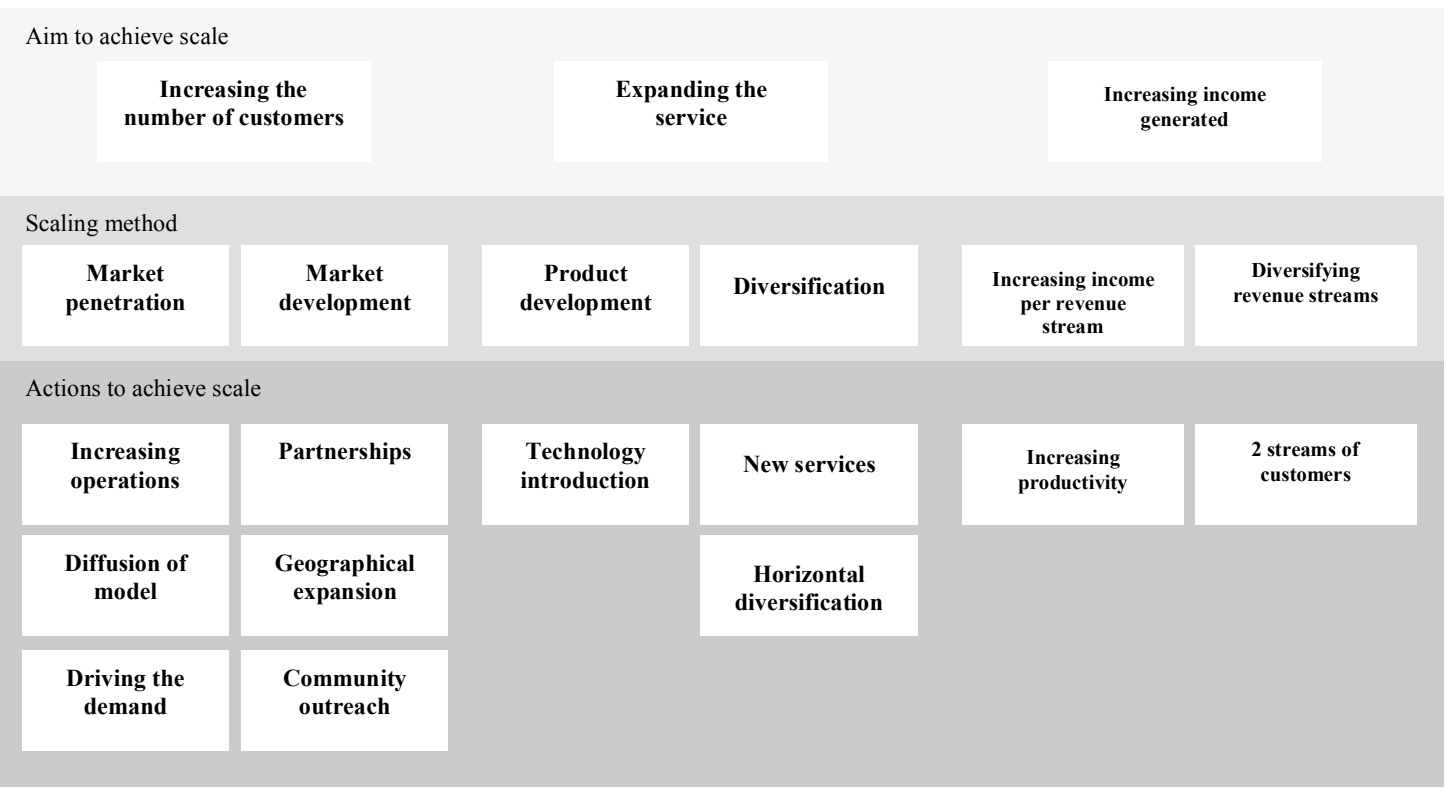

Figure 7. Aravind scaling strategies. Note: the first four methods are based on Ansoff's matrix (1988) and are complemented by 'increasing income generated' and 'diversifying revenue streams'

To spread its model to more people, Aravind increased the number of hospitals and eye care centres, diffused its model and drove demand as can be found in Figure 7. The company opened several hospitals in its first ten years of activity and worked with other hospitals to copy its model. Hospitals that failed to replicate its model were 
those that lacked strong leaders that shared the values of Aravind (source: interview). Government regulations such as the number of patients allowed in an operating room was one barrier to market penetration (source: interview). Aravind also scaled up its impact by increasing the number of people it reached through eye camps that serve the purpose of identifying patients requiring surgery in addition to raising awareness on sight problems to unreachable communities and spreading knowledge of the business.

To develop new markets, Aravind used partnerships, geographical expansion and programs to reach hard-to-reach communities. For instance, they partnered with the World Diabetes Foundation to create awareness on diabetes and diabetic retinopathy from 2003 to 2009 (Aravind, 2013). Although most hospitals are in India, hospitals in other countries, including Tanzania, Sri Lanka, Nepal, China, Indonesia, Bolivia and Sub-Saharan African nations, have been trained to replicate the model (Rangan and Thulasiraj, 2007).

In order to expand its service, Aravind introduced IT kiosks for Teleadvice. With help from the Indian Institute of Technology, Madras and n-Logue, a communications company, IT kiosks were installed with web cameras enabling patients to take a picture of their eyes and a voice description of their problem to send to a doctor (Prahalad, 2004). Aravind also successfully developed new activities (e.g., manufacturing) and new services (primary eye care). Finally, to generate more income, Aravind successfully integrated operational effectiveness in all of its operations.

\subsection{Case study Amul}

The Amul case study is organised by the evidence of scaling and approach and the timeline and strategies.

\subsubsection{Amul evidence of scaling and approach}

Amul Dairy is an Indian co-operative of three million milk producers. The Amul Model is a three-tier co-operative structure: dairy cooperative societies in villages are affiliated to a milk union at the district level which in turn is federated into a milk federation at the state level (Amul, 2011b). Its aim is to provide a fair milk supply chain in India, avoiding unfair and manipulative practices. It has grown to be the biggest milk supplier in the country with more than fifteen million associated milk producers (Amul, $2011 b)$. Milk collection is done by the village dairy society, procurement and processing by the District Milk Union, and milk and dairy products marketing by the state federation (Amul, 2011b). Amul Dairy's annual sales are approximately three billion dollars (Amul, 2011a). The company's model is based on three elements (Amul, 2011b):

- Establishment of a direct linkage between supply and demand

- Milk producer control procurement, processing and marketing (the Gujarat Cooperative Milk Marketing Federation or GCMMF is responsible for the marketing of all Amul products)

- Professional management

Amul is well known among Indian consumers for offering high-quality products at reasonable prices. It offers its farmers $80 \%$ of the consumer's dollar for milk, compared with 35\%-40\% typical in some Western markets (Deshpande, 2013).

\subsubsection{Amul timeline and strategies}


Figures 8 and 9 show that Amul Dairy began its scaling-up through diversification and market penetration. It started by increasing the number of producers in the state of Gujarat and then created a processing plant to transform excess milk into dairy products, avoiding milk losses for producers (Amul, 2013). The government partnership put in place in 1964 triggered a vast geographical expansion into all of India. At this point, sales really picked up and Amul Dairy became the leading dairy product company in India (Amul, 2013) as shown on the timeline (Figure 8).

Amul Dairy successfully expanded its customer basis internationally with sales in USA, Middle East, Asia and certain African countries. GCMMF has received the APEDA Award from Government of India for Excellence in Dairy Product Exports for the last 13 years (Amul, 2011c). Partnerships have been key for Amul Dairy's growth, especially its partnership with the government, which helped them spur India's White Revolution, the world's biggest dairy development program that made India a milksufficient nation (Amul, 2013).

To develop new markets, Amul used umbrella-brand marketing. All its products are advertised under the same brand Amul instead of developing several brands, each with their own marketing. Amul Dairy also used New Product Introduction to increase its sales, as well as developing new activities and products. For example, in 2007 it launched a probiotic ice cream. Amul diversified its activities by integrating services for cattle and research in this area. In 1964 a research and development centre was created for animal health care and breeding (Amul, 2011e). Finally, it increases the income generated by making the organisation extremely efficient (Chandra, 2005).

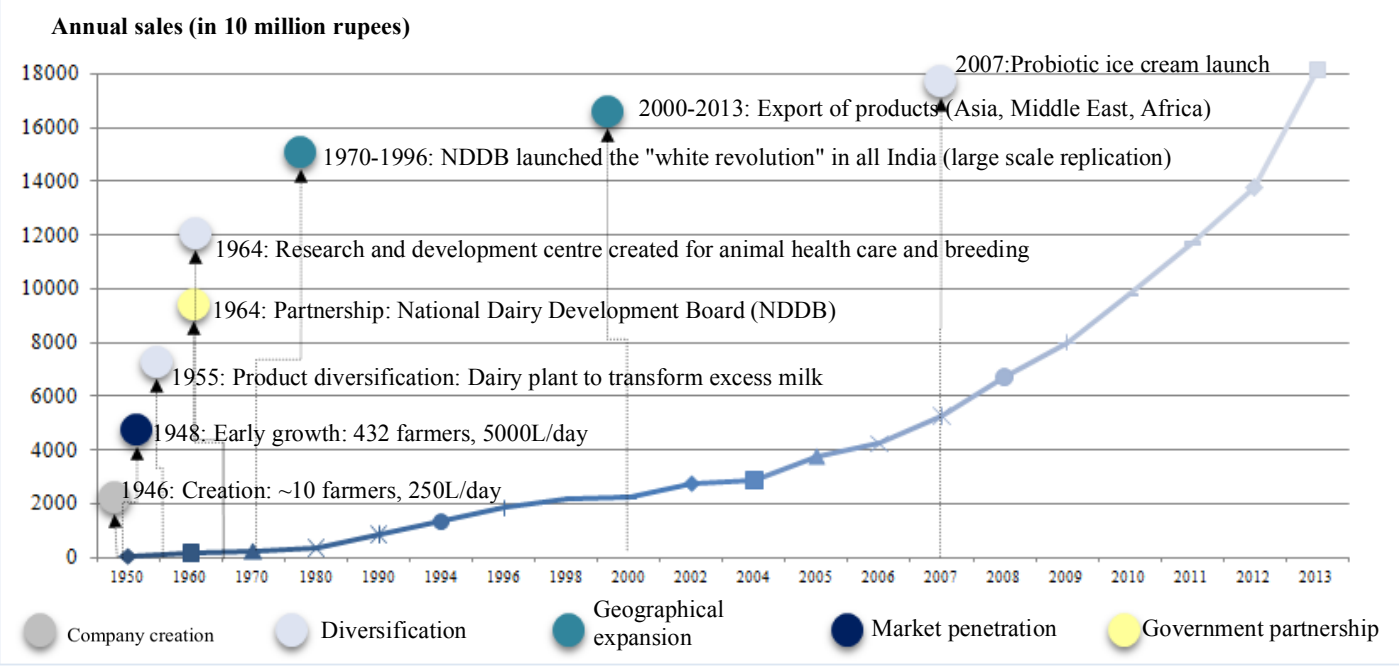

Figure 8. Amul timeline. Source: Amul (2013), Amul (2011, a), Amul (2011,b), Amul (2011,c), Amul $(2011, d)$, Amul $(2011, e)$. 


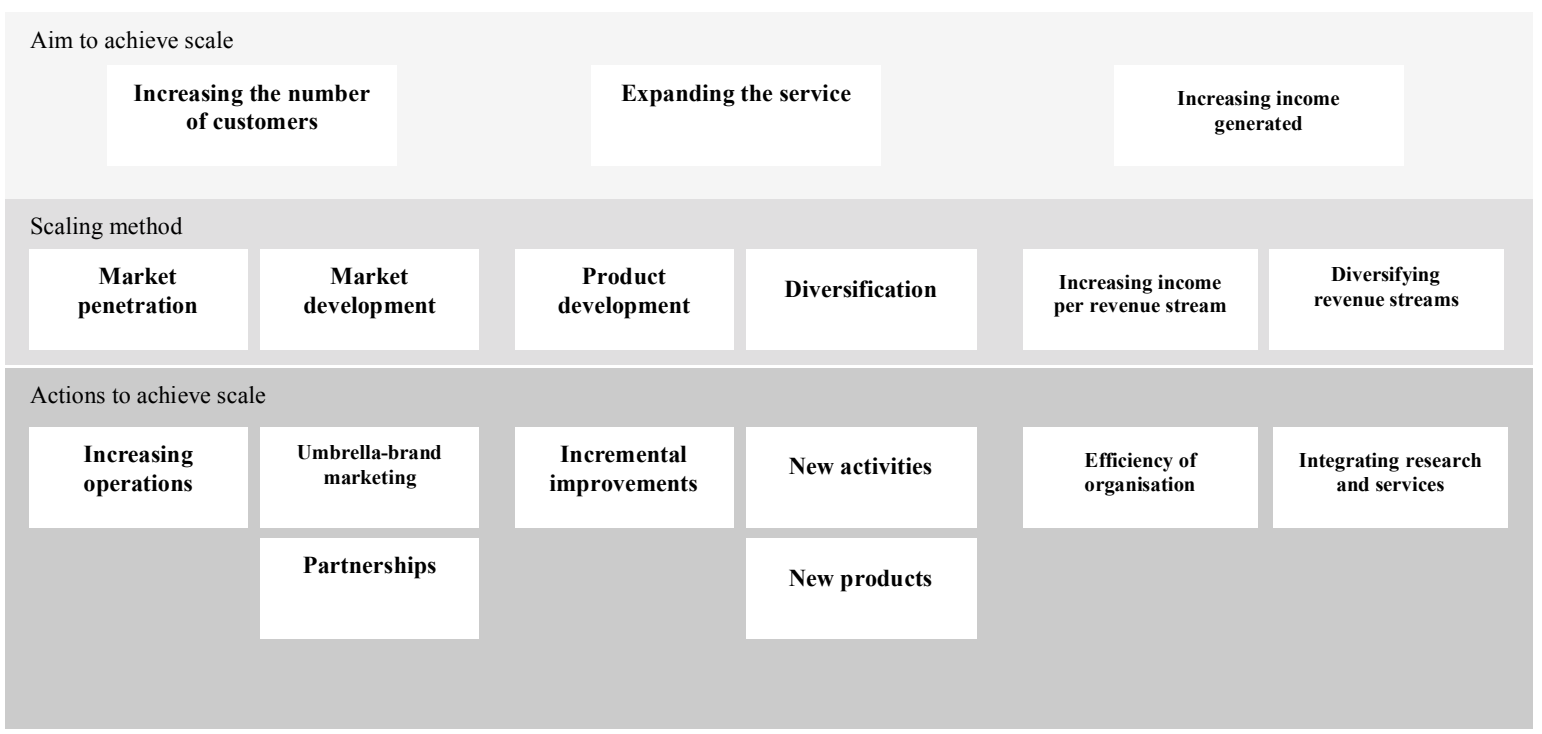

Figure 9. Amul scaling strategies. Note: the first four methods are based on Ansoff's (1988) matrix and are complemented by 'increasing income generated' and 'diversifying revenue streams'

\subsection{Cross-case analysis}

Based on the timelines and scaling strategies, Figure 10 was developed. The scalingup strategies throughout time between the three large-scale social enterprises were compared in Figure 10. Each dot corresponds to the moment (X-axis) where the company (colour of the dot) used a given method ( $\mathrm{Y}$-axis).

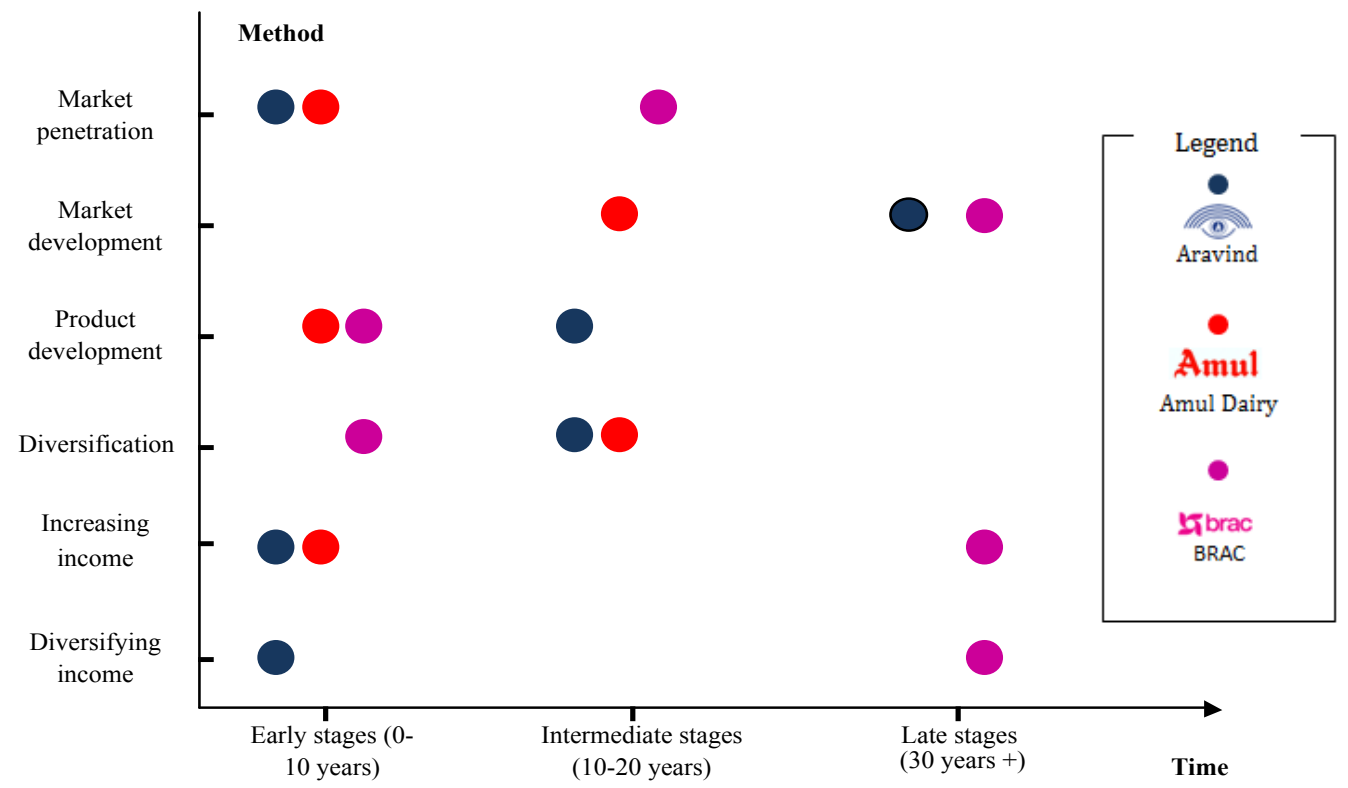

Figure 10. Comparison of scaling-up strategies over time. Note. The dots refer to the different methods employed by each of the companies for scaling up at the early, intermediate and later stages of the business' existence.

A first observation is that all the companies used almost all the different scaling-up methods at one point in their development. This indicates that all strategies are 
important to achieve scale and that companies need to mix and match different strategies.

Second, it was found that BRAC had quite a different development from the two other case studies. The company started by testing solutions, diversifying its range of activities and developing services before penetrating the market and increasing its income. BRAC, as a social business closer to the 'non-profit-end' of the spectrum (Figure 1), thus focuses more on quickly diversifying into different solutions rather than market penetration and income related scaling up methods. This is mainly due to the fact that its mission is to solve poverty, which is highly complex and systemic. Due to this, diversification was key in the early stages. On the contrary, Aravind and Amul Dairy started by market penetration and income increasing activities, because reaching economies of scale is what their business model is based on (see "developing scale up solutions" in Bocken et al., 2014). Only at the intermediate stages, these businesses focused on diversification activities. The reason of this may be related to the initial highly specific purpose of these firms: to end needless blindness and to provide affordable and fair milk supply chain in India respectively. Finally, at the late stages, market development remains important (Aravind, BRAC). BRAC also deliberately focuses on professionalisation to increase revenues and decrease cost per unit, which supported its further growth.

Although scaling-up requires a mix of several methods, there are key decisions to take such as deciding whether to improve a product or expand into another region. When a social business starts, the social business purpose appears to determine its initial strategies: whether to penetrate markets with one key product (Aravind, Amul) or diversifying to achieve a complex goal of reducing poverty (BRAC). The intermediate stages focus on all strategies as laid out by Ansoff (1980) whereas in the late stages the focus is on remaining financially viable and leveraging existing markets.

\section{Discussion}

This research seeks to combine strategies used by for-profit businesses and nonprofit organisations to gain an understanding of how social businesses can scale up their business in emerging markets.

\subsection{Definitions of scaling up and key strategies}

This research has made a couple of contributions to improve the understanding of how social businesses in emerging countries can scale up.

First 'scaling up' in this paper is defined in Section 2.2, as: "Increasing the number of customers or members of a business as well as expanding its offer and maximising its revenues until it reaches millions of people." This definition was used to analyse the case studies of Aravind, BRAC and Amul, using the "Analysis framework to clarify methods to scale up used for the case studies" in Figure 3.

Second, strategies for scaling-up were determined from three in-depth case studies. The methods identified were consistent with Ansoff's growth matrix (Ansoff, 1988). The importance of market penetration, market development, product development and diversification were underlined. However, in contrast to Ansoff's matrix, developed originally with for-profits in mind, two additional activities were identified: diversifying revenue streams (finding new types of revenue) and increasing the revenues per stream. These are similar to the organisational scale up method "financial viability" as described by Uvin and Miller (1996) for non-profit organisations. Perhaps because profit-maximisation is not the primary goal of social businesses, but rather, the 
maximisation of positive societal impact is (Berger Grove and Berg, 2014; p. 157), there is an additional need to search for funds to sustain the social business. It shows the importance of focusing on income streams in order to 'finance social impact'. Building on our definition of scaling up social impact, and our analysis framework in Figure 3, we build a revised framework in Figure 11 for scaling up social businesses. The ultimate goals of social businesses are to reach a number of customers with a specific service/ offer that has a social impact. In order to achieve these goals, the four strategies by Ansoff (1988) apply. The strategies of increasing income generated are viewed as the important outcomes that help sustain the social business. In contrast to for-profit businesses, social businesses might benefit from more subsidies because of their social goals.

Finally, the order of scaling strategies was determined in Figure 10. In the early stages a mix of all methods is used, although the social business with the broadest and most complex purpose, BRAC with an aim of reducing poverty, immediately starts with diversification. In the late stages, diversification becomes less important and the focus is on market penetration and increasing income generated to sustain the social business.

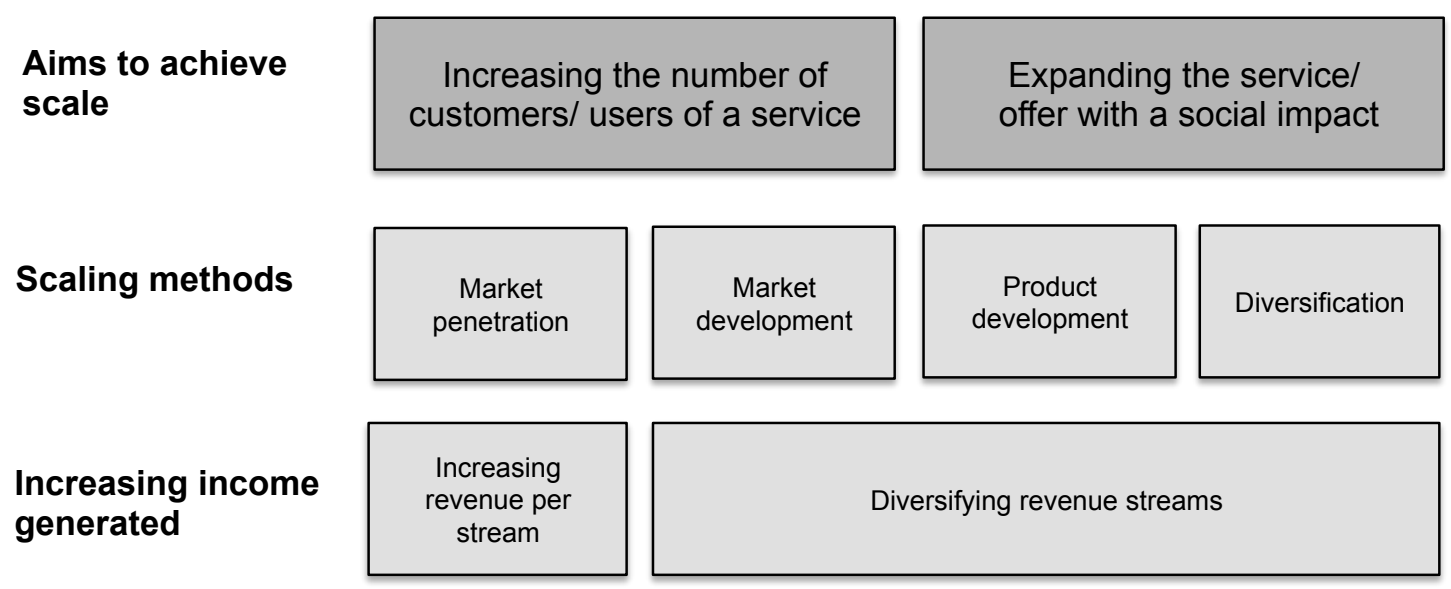

Figure 11. Framework developed for scaling up social businesses.

\subsection{New business models and achieving scale}

Choosing the best strategy requires strong leadership and a match between scalingup strategies and the mission, values and business model of the company. The three case companies each pursue the sustainable business model archetype of 'repurposing the business for society' (Bocken et al., 2014): there is a close integration of activities between the company, local communities as customers or beneficiaries and suppliers, and other stakeholder groups such as the government and schools. The business purpose drives the scaling strategies used, where in the case of more complex purposes (reducing poverty, BRAC), diversification of activities is required already at early stages of the business. Moreover, the social businesses analysed intentionally 'develop scale up solutions' (Bocken et al., 2014) for example through experimentation and stimulating replication (all cases) to grow social impact of the business. These business model archetypes appear to be highly suitable and synergistic to scale up social impact. In the future, social businesses might consider other solutions such as 'creating the functionality without the ownership' or 'product service systems' such as leasing and pay per use models (Tukker, 2004; Bocken et al., 2014) to reach an even wider customer base by charging per use and making products/ services more affordable. 


\subsection{Limitations and future work}

This paper has some limitations that could be addressed by future research. For instance, we focussed on the strategies that social businesses employ to achieve scale. However, other organisational challenges that we do not consider may arise during the scaling process. Future research could, for instance, focus on the impact of each scaling-up method in terms of both its social and business impact. Other questions worth investigating include:

- What problems appear once a social business has achieved scale?

- How can a social business maintain its social values at scale?

- Should all social businesses scale up? What are the risks of scaling-up?

Another limitation of this paper concerns the sample of cases considered. For good conceptual, substantive and methodological reasons we choose to study very large social businesses, i.e., ones that have scaled. For instance, failure or lack of scale even over a large period of time is the norm among social businesses. Studying social businesses that succeed and scale therefore provides insight into a rare phenomenon. Indeed, looking at successful social businesses automatically provides us which a contrast: why do these rare businesses succeed where most others fail? Nevertheless, future research could compare successful social businesses with ones that failed. Doing so would shed light on the limits and boundary conditions of our findings. It would also be interesting to compare large social businesses with similar for-profit businesses to understand the differences. Future research could provide more rigorous comparisons by matching social and for-profits businesses that were similar at founding but where one or more grew while the others failed.

\section{Conclusions}

This paper has developed a range of key contributions to the literature on social scaling.

First, to date there have been few practicable definitions of social scaling up. This paper developed the following definition for scaling up social businesses: "Increasing the number of customers or members of a business as well as expanding its offer and maximising its revenues until it reaches millions of people."

Second, whereas there are various frameworks for scaling up for profits and nonprofits, few in the literature have focused on social businesses. Figure 11 provides a framework for scaling up social businesses, distinguishing the key aims of increasing the number of users or customers of a service, and expanding the service to achieve social impact based on the definition developed in this paper; and scaling methods of market penetration, market development, product development and diversification based on Ansoff (1988).

Third, an understanding of the types of strategies to be used at different stages was developed based on the case studies of Aravind, Amul and BRAC. All social businesses apply all four methods of market penetration, market development, product development and diversification at some point. However, social businesses with a clear single purpose can start with 'simpler' strategies such as market penetration, whereas those with a broad purpose will need diversification. In the intermediate stages a mix of the four strategies is used. At the later stages, market penetration and a focus on optimising income become more important again to sustain the social business. 
Finally, we believe that social businesses are an interesting and important phenomenon that have huge relevance to real world practice as well as academic research. While this paper is a first step in the direction with a focus on three cases that have successfully scaled up, more research in this area is urgently needed to support the development and scaling of social businesses and our understanding of the process.

\section{References}

Ahmed S., French M. 2006. Scaling-up: the BRAC experience. BRAC Univ. J., 3 (2), $35-40$

Ahmed, D., Khondkar, M. 2010. An Analysis of Institutions and Policy Processes for Selected Antipoverty Interventions in Bangladesh. IFPRI Discussion Paper, 01046 December 2010. Available at: http://citeseerx.ist.psu.edu/viewdoc/download?doi=10.1.1.226.6325\&rep=rep1\&type=p df (accessed 18 March 2016).

Alter, K. 2007. Social Enterprise Typology. Virtue Ventures LLC.

Available at: http://www.4lenses.org/setypology (accessed 4 January 2016).

Alvord, S.H., Brown, L. D., Letts, C. W., 2004. Social Entrepreneurship and Societal Transformation: An Exploratory Study. The J. Of Appl. Behavioral Science, 40, 260282.

Amul, 2011a. Organisation. Available at: http://www.amul.com/m/organisation (accessed 28 August 2015).

Amul, 2011b, About-Us - the Amul Model, GCMMF. Available at: http://www.amul.com/m/about-us (accessed 28 August 2015).

Amul, 2011c, Exports. Available at: http://www.amul.com/m/exports (accessed 28 August 2015).

Amul, 2011d, GCMMF Awards. Available at http://www.amul.com/m/amul-pro-bioticice-cream-gets-no-1-award-at-world-dairy-summit (accessed 28 August 2015).

Amul, 2011e, ARDA, Available at http://www.amuldairy.com/index.php/cdprogrammes/arda (accessed 28 August 2015).

Amul, 2013, History. Available at: http://www.amuldairy.com/index.php/aboutus/history (accessed 28 August 2015).

Angeli, F., Kumar Jaiswal, A. 2016. Business Model Innovation for Inclusive Health Care Delivery at the Bottom of the Pyramid. Organization \& Environment, 1-22. DOI: $10.1177 / 1086026616647174$

Ansoff, H. I. 1988. The new corporate strategy. John Wiley \& Sons Inc., Somerset, New Jersey, USA.

Aravind, 2013, Aravind annual report 2012-2013, Available at: http://www.aravind.org/default/publicationscontent/publication (accessed 27 August 2015). 
Aravind, 2014, Milestones. Available at:

http://www.aravind.org/default/aboutuscontent/milestones (Acessed 28 August 2015).

B Lab. 2016. What is a Benefit Corporation? Available at: http://benefitcorp.net/ (accessed 31 May 2016).

Bloom, P. N., Chatterji, A. K. 2009. Scaling social entrepreneurial impact. Calaif. Manage. Rev., 51(3), 114-133.

Bloom, P., Chatterji, A. 2010. Scaling Social Entrepreneurial Impact. The SCALERS model. Harvard Family Research Project, XV(1).

Bloom, P.N., Smith, B.R. 2010. Identifying the drivers of social entrepreneurial impact: Theoretical development and an exploratory empirical test of SCALERS. J. of Soc. Entrep., 1(1), 126-145.

Bocken, N., Short, S. 2016. Towards a sufficiency-driven business model: Experiences and opportunities. Environmental Innovation and Societal Transitions, 18, (41-61).

Bocken, N., Short, S., Rana, P., Evans, S. 2013. A value mapping tool for sustainable business modelling. Corporate Governance, 13 (5), 482 - 497

Bocken, N.M.P., Short, S.W., Rana, P., Evans, S. 2014. A literature and practice review to develop sustainable business model archetypes. J. Clean Prod, 65, 42-56.

Bocken, N. 2015. Sustainable Venture Capital - Catalyst for Sustainable Start-up Success? 108 (Part A), 647-658.

Boyd, B., Henning, N., Reyna, E., Wang, D.E., Welch, M.D., Hoffman, A., 2009. Hybrid organizations New Business Models for Environmental Leadership. Greenleaf Publishing, Sheffield, UK.

BRAC, 2013a. BRAC annual report 2013, Available at: http://issuu.com/brac/docs/brac-annual-report-2013 (accessed 28 August 2015).

BRAC, 2013b. Targeting the Ultra Poor Briefing Note Ending Extreme Poverty. Available at: http://tup.brac.net/ (accessed 28 August 2015).

BRAC, 2013c. Microfinance at a glance, 2013. Available at: http://microfinance.brac.net/overview (accessed 25 August 2015).

BRAC. 2015. BRAC marks FI2020 week with nationwide dialogue on microfinance. Available at: https://www.brac.net/latest-news/item/340-brac-marks-fi2020-week-withnationwide-dialogue-on-microfinance (accessed 18 March 2016).

Bradach, J., Grindle, A., 2014, Transformative Scale: The Future of Growing What Works Nine strategies to deliver impact at a scale that truly meets needs, Stanford Soc. Innov. Rev., 19 February 2014.

Bradach, J. 2010, Scaling Impact, Stanford Soc. Innov. Rev., Summer 2010.

Chandra, P., 2005, The extraordinary story of Amul, Rediff India Abroad, 2005, Available at http://www.rediff.com/money/2005/sep/23spec.htm (accessed 4 January 2016) 
Chaudhary, V. M., 2014, Speech of Chairman, Vipulbhai M. Chaudhary: 39th Annual Report 2012-2013. Available at: http://www.amul.com/m/39th-annual-general-bodymeeting-held-on-25th-june-2013 (accessed 4 January 2016).

Christensen, C.M., Baumann, H., Ruggles, R., Sadtler, T.M., 2006. Disruptive nnovation for Social Change. Harvard Business Review, December.

Clark C. 2012. Scaling Social Impact: a literature toolkit for funders. Growth Philanthropy Network and Duke University. Available at: http://www.socialimpactexchange.org/webfm_send/739 (accessed 4 January 2016).

Corbin, J., Strauss, A. 1990. Grounded Theory Research: Procedures, Canons, and Evaluative Criteria. Qual. Sociol., 13 (1), 3-21.

Dees, G. 1998. The meaning of social entrepreneurship. The Kaufmann Center for Entrepreneurial Leadership and Ewing Marion Kaufmann Foundation. Available at: http://www.partnerships.org.au/Library/the_meaning_of_social_entrepreneurship.htm

Deshpande, R., Khanna T., Bijlani T. 2013. India's Amul: Keeping up with the Times, Harvard Business Review, October.

Eisenhardt, K.M. 1989. Building Theories from Case Study Research. The Academy of Management Review, 14 (4), 532-550.

Gabriel, M., 2014. Making it Big: Strategies for scaling social innovations. Nesta. Available at: http://www.nesta.org.uk/publications/making-it-big-strategies-scalingsocial-innovations (accessed 28 August 2015).

George, G., McGahan, A. M., Prabhu, J. 2012. Innovation for inclusive growth: Towards a theoretical framework and a research agenda. J. Manage. Stud., 49(4), 661-683.

Gradl, C., Jenkins, B. 2011. Tackling barriers to scale: From inclusive business models to inclusive business ecosystems. CSR Initiative, Harvard Kennedy School, Cambridge MA.

Grassl, W. 2012. Business models of social enterprise: A design approach to hybridity. ACRN J. Soc. Entrep. Perspect., 1(1), 37-60.

Grove, A., Berg, G. 2014. Social Business: Theory, Practice and Critical Perspectives, Springer, Heidelberg, New York, Dordrecht, London.

Haigh, N., Hoffman, A.J., 2012. Hybrid organizations: The next chapter of sustainable business. Organ. Dyn. 41, 126-134.

Hammond, A. L., Kramer, W. J., Katz, R. S., Tran, J. T., Walker, C. 2007. The next 4 billion: Market size and business strategy at the base of the pyramid. World Resources Institute International Finance Corporation. Available at: http://www.wri.org/publication/next-4-billion (accessed March 2016).

Hart, S. L., Christensen, C. M. 2002. The great leap. Sloan Manage. Rev., 44(1), 5156. 
IEA/ OEC, 2012. World Energy Outlook, 2012. IEA/ OECD Paris. Executive Summary pg. 7

http://www.iea.org/publications/freepublications/publication/English.pdf (accessed May 2016)

IEA/ OECD. 2015. WORLD ENERGY OUTLOOK 2015 FACTSHEET Global energy trends to 2040. Available at:

http://www.worldenergyoutlook.org/media/weowebsite/2015/WEO2015_Factsheets.pd f (accessed May 2016).

IPCC. 2014. Climate Change 2014 Syntheiss Report. Summary for Policy Makers.

Available at: https://www.ipcc.ch/pdf/assessment-

report/ar5/syr/AR5_SYR_FINAL_SPM.pdf (accessed May 2016).

Islam A., May M., 2013. Making Tuberculosis History: Community-based solutions for millions. The University Press Ltd, BRAC, Dhaka.

Kahle, H.N., Dubiel, A., Ernst, H., Prabhu, J., 2013. The democratizing effects of frugal innovation: Implications for inclusive growth and state-building. J. Indian Bus. Res. 5, 220-234.

Karamchandani, A., Kubzansky, M., Frandano, P., 2009. Emerging markets, emerging models. Available at: http://www.thegiin.org/binarydata/RESOURCE/download_file/000/000/5-2.pdf (accessed 28 August 2015).

Keuschnigg, C. 2004. Venture capital backed growth. J. of Econ. Growth, 9(2), 239261.

Korten, D.C., 1980. Community organization and rural development: a learning process approach. Public Adm. Rev. 480-511.

Kumar, N., Puranam, P. 2012. Frugal engineering: An emerging innovation paradigm. Ivey Bus. J., 76(2), 14-16.

MacMillan, S., 2013, An end in sight for extreme poverty Scaling up BRAC's graduation model for the ultra-poor, Available at: http://tup.brac.net/images/BRAC_Briefing_Document_on_TUP.pdf (accessed 10 August 2015).

Manikutty, S., Vohra, N. 2004. Aravind eye care system: giving them the most precious gift. Case study, Indian Institute of Management.

Mashelkar, R.A., Sridhar, R., 2008. Gandhian Engineering is not just for the poor, IDEAS-RS.

Matin, I., Yasmin, R. 2004. Challenges of Scaling-Up a Program for the Poorest: BRAC's IGVGD Program. The International Bank for Reconstruction and Development / THE WORLD BANK. Available at:

http://info.worldbank.org/etools/docs/reducingpoverty/case/109/fullcase/Bangladesh\% 20BRAC\%20Full\%20Case.pdf

May, M., 2011. Making Tuberculosis History: Community-based Solutions for Millions. The University Press Limited, Dhaka, Bangladesh. 
McDonald D., Ruiters G., 2013, Alternatives to Privatization: Public Options for Essential Services in the Global South. HSRC Press, Capetown, SA.

Mehta, P., Shenoy, S., 2011, Infinite Vision. Berrett-Koehler Publishers, San Francisco.

Murray, R., Caulier-Grice, J., Mulgan, G. 2010. The open book of social innovation. NESTA, London.

Polak, P. 2009. Out of poverty: What works when traditional approaches fail. BerrettKoehler Publishers, San Francisco.

Porter, M.E., 1998. Competitive Strategy: Technique for analysing industries and competitors. Free Press, New York.

Prabhu, J., Jain, S. 2015. Innovation and entrepreneurship in India: Understanding jugaad. Asia Pac. J. Manage. 32. 4, 843-868.

Prahalad, C. K. 2004. The Fortune at the Bottom of the Pyramid. Pearson Education India.

Prahalad, C. K., Hart, S. L. 1999. Strategies for the bottom of the pyramid: creating development. Available at: http://www.bus.tu.ac.th/usr/wai/xm622/conclude\%20monsanto/strategies.pdf (accessed 28 August 2015).

Prahalad, C. K., Hammond, A. 2002. Serving the world's poor, profitably. Harvard business review, 80(9), 48-59.

Prahalad, C. K., Mashelkar, R. A. 2010. Innovation's holy grail. Harvard Business Review, 88 (7-8), 132-141.

Radjou, N., Prabhu, J., Ahuja, S. 2012. Jugaad innovation: Think frugal, be flexible, generate breakthrough growth. John Wiley \& Sons Inc., USA.

Rangan, V.K., 1993. The Aravind Eye Hospital, Madurai, India: In Service for Sight, Harvard Business Press, April 1993 (revised May 2009).

Rangan, V. K., Thulasiraj, R. D. 2007. Making sight affordable (innovations case narrative: the Aravind eye care system). Innovations, 2(4), 35-49.

Royal Society. 2012. People and the Planet. Royal Society, April 2012. Available at: https://royalsociety.org/topics-policy/projects/people-planet/ (accessed 12 May 2016)

Rubin, H. 2001, The Perfect Vision of Dr. V., Fast Company. http://www.fastcompany.com/42111/perfect-vision-dr-v (accessed 25 August 2015).

Saleh, A., May, M., 2013. So We've Scaled Up, Now What? Stanford Soc. Innov. Rev. $1-3$.

Seawright, J., Gerring, J. 2008. Case selection in case study research. Public Research Quarterly, 61 (2), 294-308.

Shanmugalingam, C., Graham, J., Tucker, S., Mulgan, G. 2011. Growing social ventures. The role of intermediaries and investors: who they are, what they do, and 
what they could become. The Young Foundation \& NESTA. Available at: http://youngfoundation.org/wp-content/uploads/2012/10/Growing-Social-Ventures2011.pdf (accessed 4 January 2016).

Silberston, A. 1972. Economies of Scale in Theory and Practice. The Economic Journal, 82 (325). Special Issue: In Honour of E.A.G. Robinson. 369-391

Smillie, I. 2009. Freedom from want: The remarkable success story of BRAC, the global grassroots organization that's winning the fight against poverty. Kumarian Press, Sterling, VA, USA, 2009.

Soman, D., Kumar, V., Metcalfe, M., Wong, J., 2012. Beyond great ideas: a framework for going global with local innovation. Rotman Magazine, 52-55.

Stubbs, W., Cocklin, C., 2008. Conceptualizing a 'sustainability business model', Organization \& Environment, 21, 103-127.

Thulasiraj, R. D., Dhivya, R., 2014, Community Eye Health Journal, Vol. 27 No. 85 2014 pp $07-08$.

Tukker, A. 2004. Eight types of product-service system: eight ways to sustainability? Experiences from SusProNet. Bus. Strat. Environ., 13(4), 246-260.

Uvin, P., Miller, D., 1996. Paths to Scaling-up: Alternative Strategies for Local Nongovernmental Organizations. Human Organization: Fall 1996, 55 (3), 344-354.

World Diabetes Foundation, 2014, Diabetes eye care, Available at: http://www.worlddiabetesfoundation.org/projects/tamil-nadu-india-wdf02-039 (accessed 10 August 2015).

Yin, R. K., 2013, Case Study Research Design and Methods, 5th ed. SAGE Publications.

Yasunaga, M. 2014. NON-FORMAL EDUCATION AS A MEANS TO MEET LEARNING NEEDS OF OUT-OF-SCHOOL CHILDREN AND ADOLESCENTS. UNESCO Institute of Statistics (UIS) and the United Nations Children's Fund (UNICEF), 2 May 2014. Available at: http://allinschool.org/wpcontent/uploads/2015/01/OOSC-2014-Non-formal-education-for-OOSC-final.pdf (accessed 18 March 2016).

Yunus, M., Jolis, A., 1998. Banker to the Poor: The Story of the Grameen Bank. Aurem Press Ltd, London, UK.

Yunus, M., 2010. Building social business: the new kind of capitalims that serves humanity's most pressing needs. Public Affairs, New York.

Yunus, M., Moingeon, B., Lehmann-Ortega, L. 2010. Building social business models: lessons from the Grameen experience. Long Range Plann., 43 (2-3), 308-325. 


\section{Appendix A}

\section{Questionnaire}

\section{Company}

Product/service

Type of Business

\section{Business}

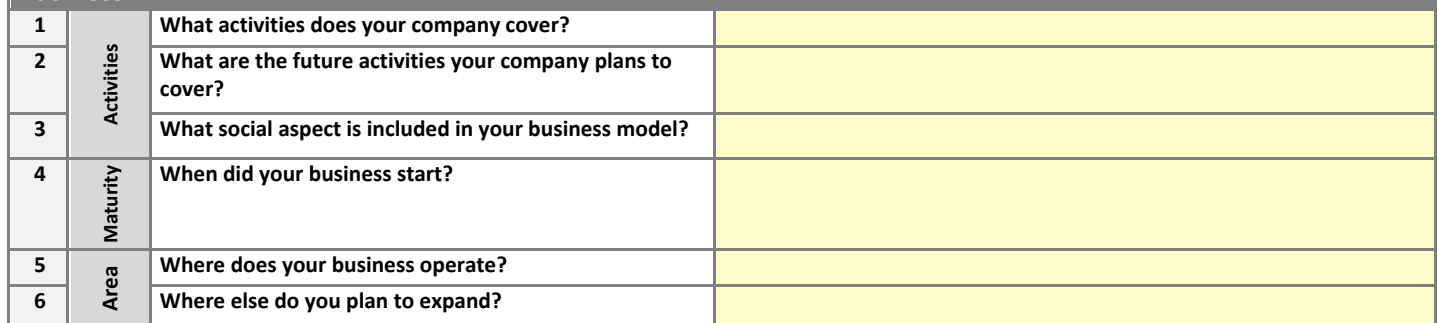

Scale
1 What is the current scale of the business?

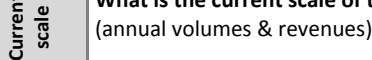
2 递 $\frac{0}{\pi}$ What are your scaling-up plans for the next 6 months?

Scaling up

\begin{tabular}{|c|c|c|c|c|c|c|c|}
\hline 1 & \multirow{7}{*}{ 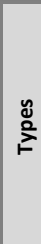 } & What types of scaling-up have you done? (When, why?) & Yes/No & When? & Why? & Issues & Success factors \\
\hline 2 & & * Market penetration & & & & & \\
\hline 3 & & * Market development & & & & & \\
\hline 4 & & * Product/service development & & & & & \\
\hline 5 & & * Diversification (both market and product development together) & & & & & \\
\hline 6 & & *Increasing income per revenue stream & & & & & \\
\hline 7 & & * Diversifying income streams & & & & & \\
\hline 8 & \multirow{8}{*}{ 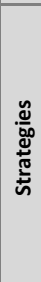 } & What strategies have you used to scale up? & Yes/No & When? & Why? & Issues & Success factors \\
\hline 9 & & * Replication & & & & & \\
\hline 10 & & * Expansion into another country & & & & & \\
\hline 11 & & * Partnerships & & & & & \\
\hline 12 & & ${ }^{*}$ Horizontal diversification & & & & & \\
\hline 13 & & * Diffusion & & & & & \\
\hline 14 & & * Other & & & & & \\
\hline$\overline{15}$ & & & & & & & \\
\hline
\end{tabular}

